ISSN (print): 1698-6180. ISSN (online): 1886-7995

www.ucm.es/info/estratig/journal.htm

Journal of Iberian Geology 38 (1) 2012: 31-52

http://dx.doi.org/10.5209/rev_JIGE.2012.v38.n1.39204

\title{
An active zone characterized by slow normal faults, the northwestern margin of the València trough (NE Iberia): a review
}

\author{
Una zona activa caracterizada por fallas normales lentas, el margen \\ noroccidental del surco de Valencia (NE Iberia): una revisión
}

\author{
H. Perea ${ }^{1 *+}$, E. Masana ${ }^{2}$, P. Santanach ${ }^{2}$ \\ ${ }^{1}$ LATTEX - IDL, Fac. Ciências Universidade de Lisboa, Ed.C6, Campo Grande 1749-016 Lisboa, Portugal \\ ${ }^{2}$ Dept. Geodinàmica i Geofísica, Universitat de Barcelona, Martí Franqués, s/n, 08028 Barcelona, Spain \\ *corresponding author: e-mail: hperea@utm.csic,es; phone: (+34)932309500 (ext. 1514)
}

Received: 02/08/2011 / Accepted: 15/04/2012

\begin{abstract}
The northwestern margin of the Valencia trough is an area of low strain characterized by slow normal faults and low to moderate seismicity. Since the mid 1990s this area has been the subject of a number of studies on active tectonic which have proposed different approaches to the location of active faults and to the calculation of the parameters that describe their seismic cycle. Fifty-six active faults have been found and a classification has been made in accordance with their characteristics: a) faults with clear evidence of large paleo-, historic or instrumental earthquakes (2/56); b) faults with evidence of accumulated activity during the Plio-Quaternary and with associated instrumental seismicity $(7 / 56)$; c) faults with evidence of accumulated activity during the Plio-Quaternary and without associated instrumental seismicity $(17 / 56)$; d) faults with associated instrumental seismicity and without evidence of accumulated activity during the Plio-Quaternary (30/56), and e) faults without evidence of activity or inactive faults. The parameters that describe the seismic cycle of these faults have been evaluated by different methods that use the geological data obtained for each fault except when paleoseismological studies were available. This classification can be applied to other areas with low slip faults because of the simplicity of the approaches adopted. This study reviews the different approaches proposed and describes the active faults located, highlighting the need a) to better understand active faults in slow strain zones through paleoseismological studies, and b) to include them in seismic hazard studies.
\end{abstract}

Keywords: active faults; seismic cycle; active tectonics; paleoseismology; València trough; Iberian Peninsula

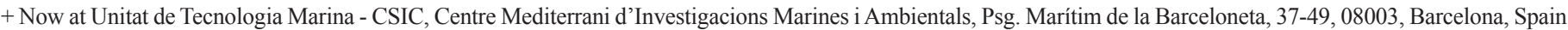


Perea et al. / Journal of Iberian Geology 38 (1) 2012: 31-52

\section{Resumen}

El margen noroccidental del surco de Valencia es una zona de baja deformación caracterizada por fallas normales lentas y una sismicidad entre baja y moderada. Desde mediados de los años 90 esta ha sido una zona objeto de varios estudios de tectónica activa donde se han propuesto diferentes aproximaciones para localizar fallas activas y obtener los parámetros que describen el ciclo sísmico de cada una de ellas. Se han localizado 56 fallas activas y se ha propuesto una clasificación de estas de acuerdo con las características que presentan: a) Fallas con claras evidencias de grandes terremotos prehistóricos, históricos o instrumentales (2/56); b) Fallas con evidencias de actividad acumulada durante el Plio-Quaternario y con sismicidad instrumental asociada (7/56); c) Fallas con evidencias de actividad acumulada durante el Plio-Quaternario y sin sismicidad instrumental asociada (17/56); d) Fallas con sismicidad instrumental asociada y sin evidencias de actividad acumulada durante el Plio-Quaternario (30/56); y e) Fallas sin evidencias de actividad o fallas inactivas. Se han estimado los parámetros que describen el ciclo sísmico de las fallas activas a través de diferentes métodos que integran la información geológica dada para cada falla, excepto cuando había información paleosismológica disponible. Esta clasificación pueden ser aplicadas a otras areas con fallas lentas dada la simplicidad de las aproximaciones utilizadas. Este trabajo revisa las diferentes aproximaciones propuestas y describe las fallas activas en la zona, destacando la necesidad a) de mejorar el conocimiento que se tiene de las fallas activas en zonas de baja deformación mediante estudios de paleosismología y b) de introducir estas fallas en estudios de peligrosidad sísmica.

Palabras clave: fallas activas; ciclo sísmico; tectónica activa; paleosismología; Surco de Valencia; Península Ibérica

\section{Introduction}

Intraplate zones are characterized by slow deformation. As a result, these zones accumulate low strain and display a small number of earthquakes, most of them low to moderate magnitude or intensity in contrast to plate boundary zones that show higher seismic activity and larger earthquakes. However, in intraplate areas, extremely damaging moderate and large earthquakes have also occurred (e.g. the 1356 Basel earthquake with intensity IX, estimated magnitude (M) 6.0 to 6.9 and between hundreds and thousands of casualties; the 1811 and the $1812 \mathrm{New}$ Madrid earthquakes with intensity IX and an estimated magnitude around 7.0; the 2001 Gujarat earthquake with intensity X, magnitude 7.6 to 7.7 and around 20000 casualties) and will therefore occur. Active faults in intraplate zones are usually characterized by slip rates ranging from 0.1 to $0.01 \mathrm{~mm} /$ year, and consequently, the recurrence intervals for large earthquakes range between $10^{3}$ and $10^{5}$ years (Villamor and Berryman, 1999). As a result, there is a lack of information about the seismic activity of these faults since the seismic catalogs only cover a very small part of their seismic cycle. Therefore, the majority of potentially active faults may not have accumulated enough geological evidence to confirm their activity, assess the size of potential earthquakes or determine the date of the last major earthquake. The lack of information about potentially seismic faults in these zones has implications for the seismic resistant regulations, which could result in casualties and considerable economic loss.

The northwestern margin of the València trough, located in the northeast of the Iberian Peninsula (Fig. 1), is an intraplate zone where large earthquakes have occurred. Because of the high population density and the location of some critical facilities, this region is highly vulnerable, and consequently has been the subject of several research projects focused on active tectonics and paleoseismology (CSN-ENRESA DATACión project, UE PALEosis, FAUST and SAFE projects). The present paper reviews the current knowledge of active faults in the València trough. The first part provides a summary of the geological and seismological setting of the València trough. The second part describes the different approaches used to locate, classify and evaluate the seismic parameters of the active faults. And finally, a short description of the main active faults in the area is presented.

\section{Geological and seismotectonic settings}

The evolution of the València trough is linked to the evolution of the Iberian microplate, which has been controlled by the opening of the Atlantic Ocean. The opening of the ocean led to the separation of the microplate from the African and Eurasian plates during the Mesozoic, and to its current integration into the Eurasian plate (Pitman and Talwani, 1972; Patriat et al., 1982; Savostin et al., 1986; Dewey et al., 1989). A number of extensional basins (the València Trough, the Alboran Sea, the LigurianProvençal, Algerian and the Tirrenian) were formed in the extensional back-arc area of the subduction of Africa beneath Eurasia. This extension began in the Neogene during the convergence between the African and Eurasian plates (e.g. Malinverno and Ryan, 1986; Royden, 1993; Serri et al., 1993; Gueguen et al., 1998; Doglioni et al., 1999; Jolivet et al., 1999; Gelabert et al., 2002). Two tectonic phases have been defined in the València trough since the Neogene (Roca, 1992; Roca and Guimera, 1992; Roca, 1996; Roca et al., 1999a; Roca, 2001; 


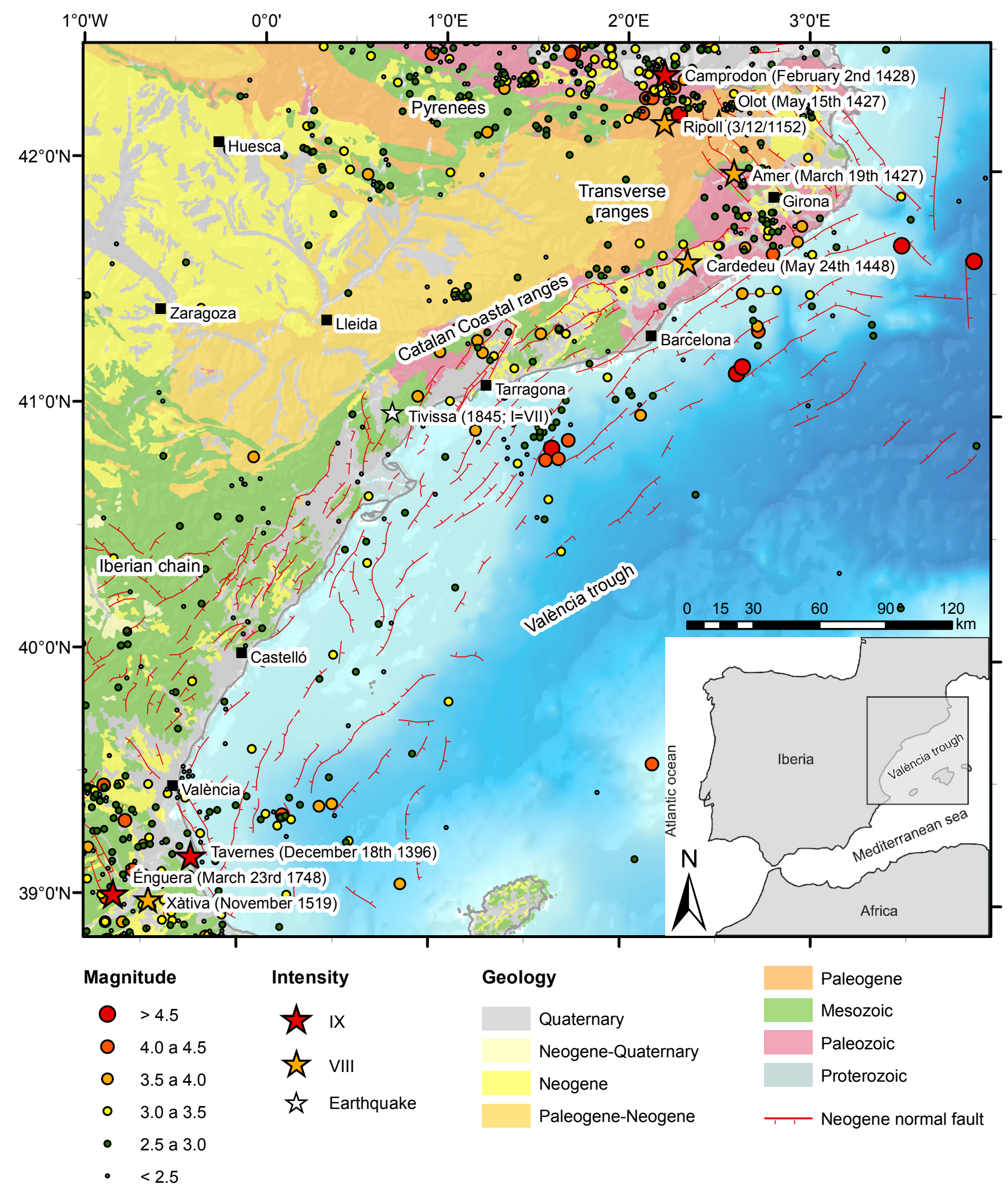

Fig. 1.- Simplified geological map of the northeastern Iberian Peninsula (modified from IGME, 1994), showing the position of the Neogene normal faults (Roca, 1992; Roca and Guimerà, 1992) and the historical earthquakes with intensity equal to and higher than VIII. Instrumental seismicity reported by the Instituto Geográfico Nacional earthquakes catalog.

Fig. 1.- Mapa geológico simplificado del noroeste de la Península Ibérica (modificado del IGME, 1994), donde se muestra la posición de las fallas normales Neógenas (Roca, 1992; Roca y Guimerà, 1992) y de los terremotos históricos con intensidad igual o mayor a VIII. Sismicidad instrumental dada en el catálogo de terremotos del Instituto Geográfico Nacional. 


\section{TRENCH 1 - SOUTH WALL}
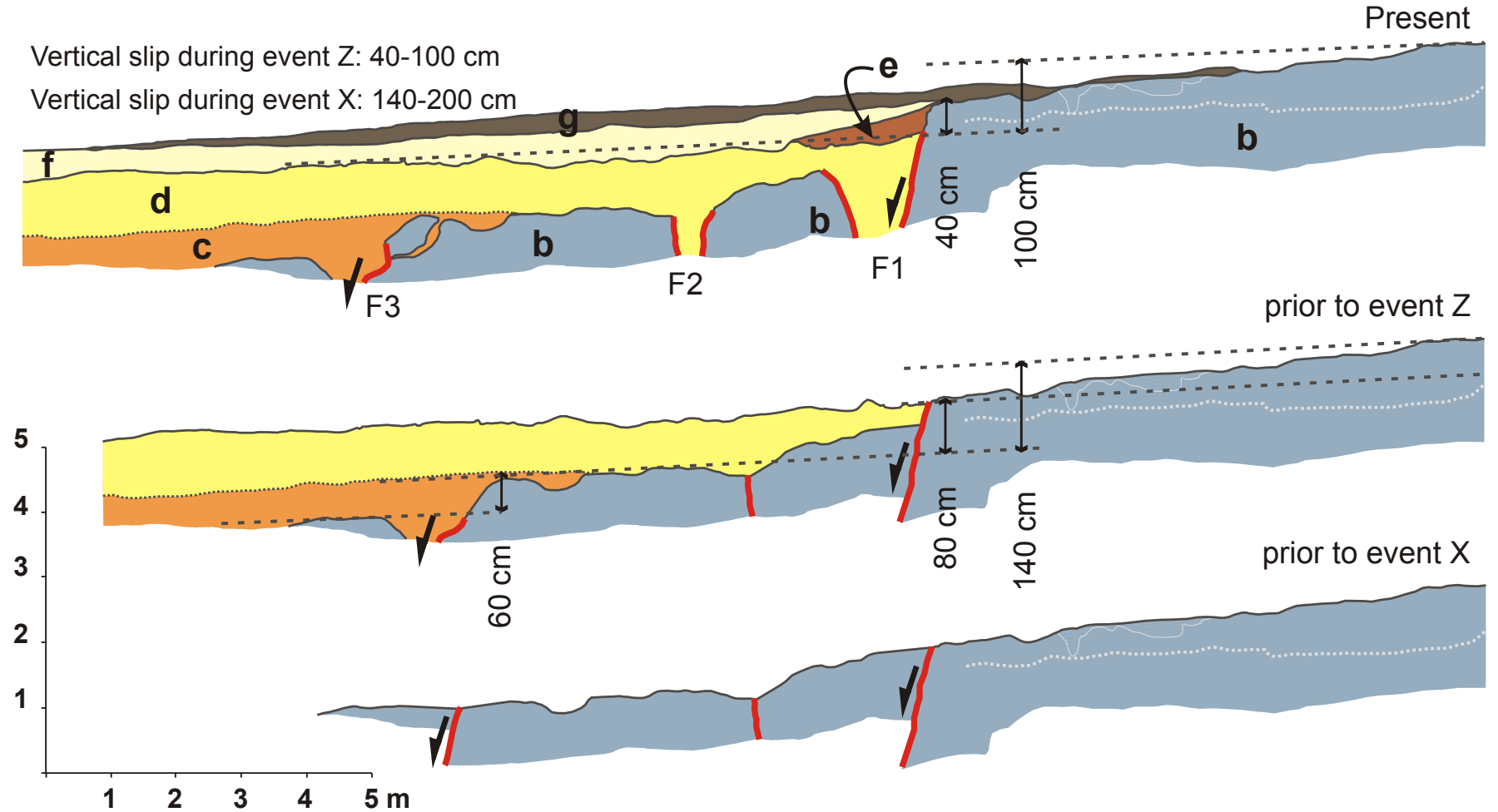

Fig. 2.- Restoration of the deformation produced by two paleoseismic events, events $\mathrm{X}$ and Z, recognized in trench 1 (southern wall) dug at the site of the Golf court on the El Camp fault (modified from Masana et al., 2001b). Event X, the older one, is evidenced by a buried fault scarp. This event was dated between 125000 and 50000 years BP and the restoration allowed us to calculate a dip-slip of 140 to $200 \mathrm{~cm}$. Event $Z$ with a vertical slip ranging between 40 and $100 \mathrm{~cm}$ is evidenced by the presence of a colluvial wedge and its preferred age is 3000 years BP (Masana, 1995 and 1996; Masana et al., 2001a and 2001b; Santanach et al., 2001; Perea et al., 2003; Perea, 2006; Perea et al., 2006; Santanach et al., 2010).

Fig. 2.- Restitución de la deformación producida por los dos eventos paleosísmicos, eventos X y Z, reconocidos en la trinchera 1 (pared sur) escavada en el sitio del Campo de Golf en la falla de El Camp (modificado de Masana et al., 2001b). El evento X, el más antiguo, está evidenciado por un escarpe de falla enterrado. Este evento fue datado entre 125000 y 50000 años BP y la restitución permitió calcular un desplazamiento vertical de 140 a $200 \mathrm{~cm}$. El evento Z con un desplazamiento vertical entre 40 y $100 \mathrm{~cm}$ está evidenciado por la presencia de una cuña coluvial y su edad mas probable sería de 3000 años BP (Masana, 1995 and 1996; Masana et al., 2001a and 2001b; Santanach et al., 2001; Perea et al., 2003; Perea, 2006; Perea et al., 2006; Santanach et al., 2010).

Gaspar-Escribano et al., 2004): the rifting phase and the thermal subsidence phase. The rifting phase lasted from the late Oligocene to middle Miocene during which a NE-SW trending rift system with a total extension of 7.1 $\mathrm{km}$ developed. The thermal subsidence phase is characterized by moderate tectonic activity mainly localized along the borders of the basin, and by a total extension of $4.1 \mathrm{~km}$ since the middle Miocene.

The València trough is a large NE-SW trending basin. The northwestern margin of the basin (Fig. 1) is constituted by a horst and graben system that controls the range and basin morphology of the coastal chains of the northeastern Iberian Peninsula. In addition, the ranges are mainly formed by Variscan basement rocks and a Mesozoic cover. The basins are filled with Neogene sediments, including Quaternary deposits. The extensional faults are superimposed on the large compressive units that arose during the Paleogene (Pyrenees and Iberian chain). The main faults are listric, have normal dip slip, accumulate kilometric displacements, and produced a considerable crustal thinning on the axis of the basin. Furthermore, they branch into the basal detachment level at 13-15 km depth (Roca and Guimera, 1992; Roca, 1996; Sàbat et al., 1997; Vidal et al., 1997; Roca et al., 1999a; Vergés and Sàbat, 1999; Roca, 2001; Gaspar-Escribano et al., 2004).

The extensional stress of the present stress field in eastern Iberia is approximately perpendicular to the strike of the major normal faults as has been the case since the start of the Neogene. This stress field has been evaluated using focal mechanisms (Goula et al., 1999; Herraiz t al., 2000) and borehole breakout data (Schindler et al. 1998). Because this stress field is similar to the one that caused 
the normal faults, all the major Neogene normal faults are potentially capable of being active and, thus, trigger large earthquakes.

In historical times, some large earthquakes have been felt in the northwestern margin of the València trough: Ripoll in 1152 (I=VIII), Tavernes in 1396 (I=IX), the Catalan Seismic crisis in 1427 and 1428 (Amer I=VIII, Olot I=VIII and Camprodon I=IX), Cardedeu in 1448 (I=VIII), Xàtiva in 1519 (I=VIII) and Énguera-Montesa in 1748 (I=IX). Nevertheless, at present the zone shows low seismic activity (Fig. 1) in terms of magnitude (the maximum instrumental earthquake reached $\mathrm{m}_{\mathrm{bLg}}=5.1$ ) and number of reported earthquakes (Olivera et al., 1992; Perea, 2006; Perea et al., 2006). Instrumental seismicity is mainly shallow given that $95 \%$ of the earthquake hypocenters are located between the surface and a depth of 20 km (Perea, 2006; Perea et al., 2006).

The geographical distribution of earthquakes along the northwestern margin of the València trough shows three areas of concentration (Fig. 1) a) the Pyrenees a- March 19th 1427 earthquake
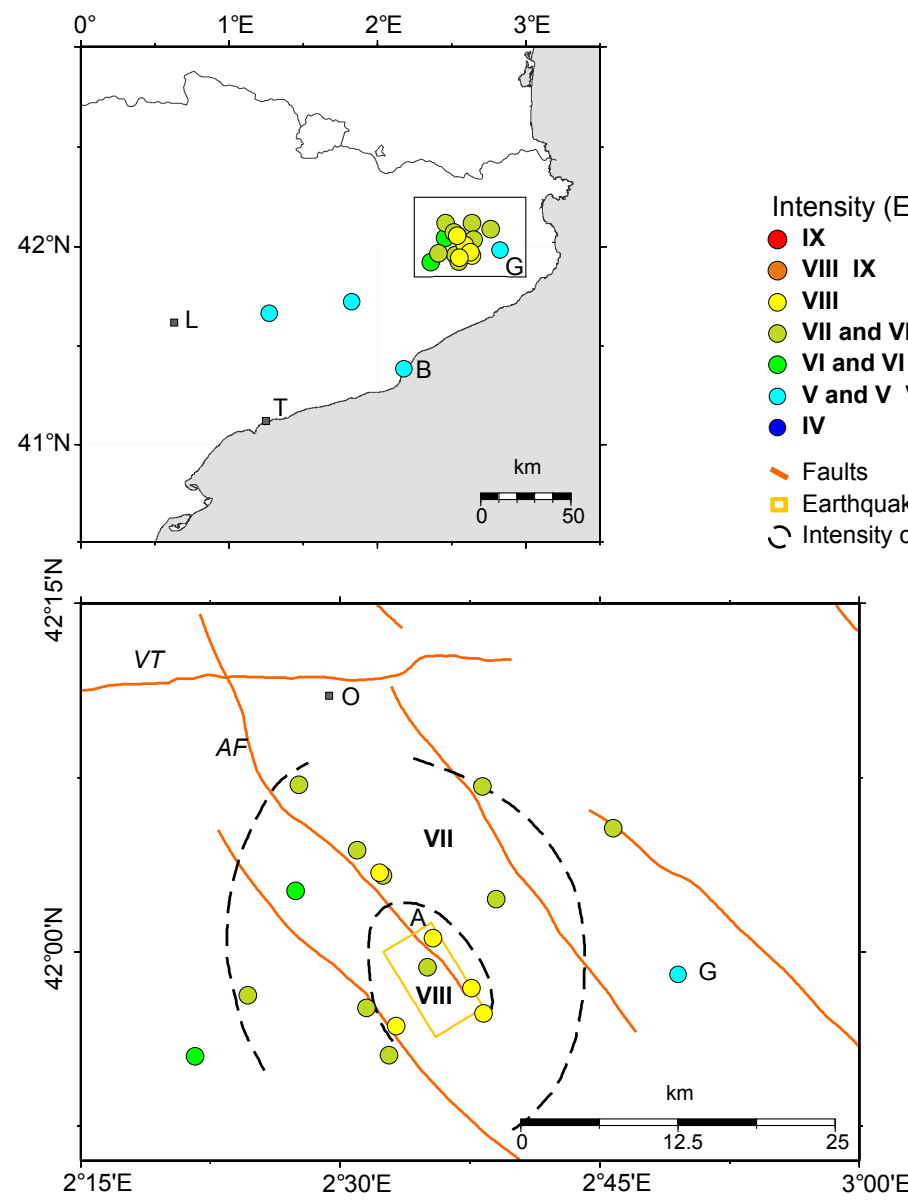

b- May 15th 1427 earthquake

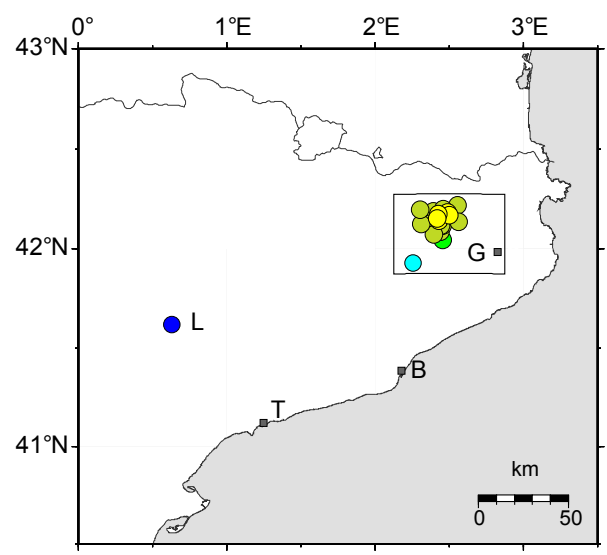

Intensity (EMS- 98)

IX

VIII IX

VII and VII VIII

- VI and VI VII

V and $\mathbf{V ~ V I}$

- IV

Faults

Earthquake source
$\frown$ Intensity contours

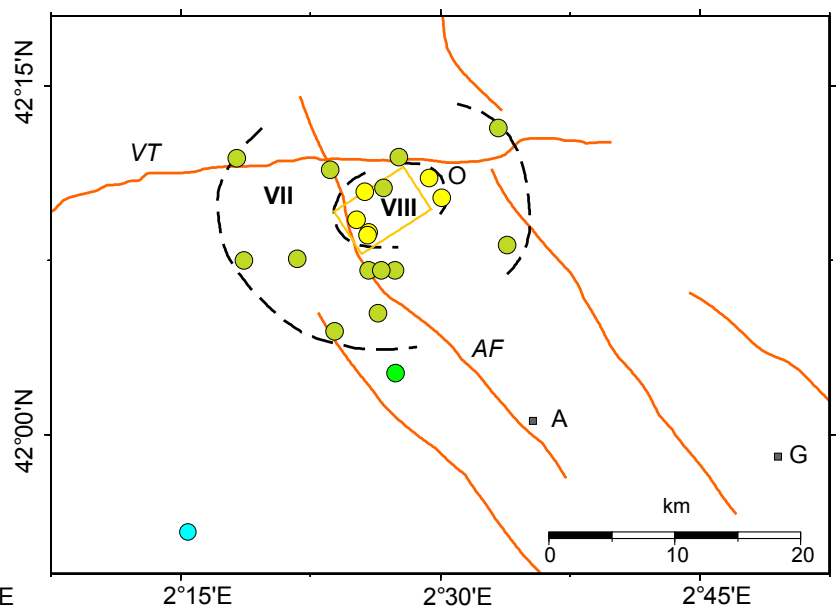

Fig. 3.- Maps (modified from Perea, 2009) showing the distribution of the intensity data points and contours (Olivera et al., 2006) and the location of the source areas calculated using the method proposed by Gasperini et al. (1999) corresponding to a) the March $19^{\text {th }} 1427$ earthquake near the town of Amer; contours corresponding to $\mathrm{I}_{\text {EMS-98 }}$ VIII and VII, and to b) the May $15^{\text {th }} 1427$ earthquake that occurred near the town of Olot; contours corresponding to $\mathrm{I}_{\text {EMS-98 }}$ VIII and VII. Note the close location of the source areas of both earthquakes and the Amer fault. This correspondence suggests that the Amer fault caused both earthquakes and probably the earthquake of February $2^{\text {nd }} 1428$ too (Perea, 2009). Cities/towns: A: Amer; B: Barcelona; G: Girona; L: Lleida; O: Olot; T: Tarragona. Faults (italics): AF: Amer normal fault; VT: Vallfogona thrust.

Fig. 3.- Mapa (modificado de Perea, 2009) que muestra la distribución de los puntos de intensidad y las isosistas (Olivera et al., 2006) y la localización de las áreas fuente calculadas utilizando el método propuesto por Gasperini et al. (1999) correspondientes: a) al terremoto del 19 de Marzo de 1427 cerca de la población de Amer; isosistas correspondientes a las IEMS-98 de VIII y VII; y b) al terremoto del 15 de Mayo de 1427 que ocurrió cerca de la población de Olot; isosistas correspondientes a las IEMS-98 de VIII y VII. Nótese la cercanía entre las áreas fuente de ambos terremotos y la falla de Amer. Esta correspondencia sugiere que la falla de Amer causó los dos terremotos y probablemente también el del 2 de Febrero de 1428 (Perea, 2009). Ciudades: A: Amer; B: Barcelona; G: Girona; L: Lleida; O: Olot; T: Tarragona. Fallas (en itálicas): AF: Falla normal de Amer; VT: Cabalgamiento de Vallfogona. 
Fig. 4.- Inset: Geometrical construction that shows how the fault plane is projected onto the surface (transparent dark gray rectangle) and how the earthquake epicenter produced on the fault plane is located inside its surface projection given that the epicenter in the surface point nearest to the hypocenter. Therefore, all the earthquakes located inside the fault plane projection are assumed to be produced by the corresponding fault (modified from Perea $e t$ al., 2006). Map showing the Montagut and Amer faults area (modified from Perea, 2006). The red line shows the surface localization of the Montagut fault, the transparent dark gray polygon bounded by a black dashed line shows the surface projection of the fault plane. The squares correspond to the historical earthquakes, the solid circles to the epicenters of the instrumental earthquakes and the dotted circles to the horizontal location error of the earthquakes. The transparent red circles correspond to the earthquakes that could have been produced by the Montagut fault given that they are located inside the fault plane surface projection or because their horizontal locational error suggests this possibility.

Fig. 4.- Inserción: Construcción geométrica que muestra como se proyecta el plano de falla en la superficie (rectángulo transparente de color gris oscuro) y como los epicentros de los terremotos producidos en el plano de falla se localizan dentro de la proyección en superficie dado que el epicentro es el punto en superficie más cercano al hipocentro. Así, todos los terremotos localizados dentro de la proyección en superficie del plano de falla se asumen como producidos por la falla correspondiente (modificado de Perea et al., 2006). Mapa que muestra la zona donde se localizan las fallas de Montagut y Amer (modificado de Perea, 2006). La línea roja muestra la localización en superficie de la traza de la falla de Montagut, el polígono transparente de color gris oscuro delimitado por una línea negra discontinua muestra la proyección en superficie del plano de falla. Los cuadrados corresponden a la localización de los terremotos históricos, los círculos a la de los epicentros de los terremotos instrumentales y los círculos punteados al error de localización de los terremotos. El círculo transparente de color rojo corresponde a los terremotos que podrían haber sido generados por la falla de Montagut dado que están localizados dentro de la proyección en superficie del plano de falla o debido a que su error de localización horizontal contempla esta posibilidad.

and Transverse ranges to the north; $b$ ) the northern and central Catalan Coastal ranges; and c) the south-eastern Iberian chain and north-eastern termination of the Betic cordillera, to the South (Perea, 2006; Perea et al., 2006). In contrast, between the southern Catalan Coastal ranges and the eastern termination of the Iberian chain, earthquakes are scarce and, consequently, this area could be described as seismically silent. However, in this area the 1845 Tivissa earthquake (I=VII; Fig. 1) occurred (Font et al., 2010), and large earthquakes have been attributed to the El Camp fault as confirmed by paleoseismological studies (Masana, 1995; Masana et al., 2001a and 2001b; Santanach et al., 2001; Perea et al., 2003; Perea, 2006; Perea et al., 2006; Santanach et al., 2010).

\section{Approaches to the identification, classification and characterization of active faults}

\subsection{Identification of active faults}

Different approaches have been adopted to the identification and classification of active faults in the Valencia trough (Perea, 2006; Perea et al., 2006). These are based on a) the definition of the relationship between prehistoric, historic and instrumental seismicity and faults; and b) the geomorphological evidence of activity accumulated during Plio-Quaternary times along the mapped faults. Only faults longer than $10 \mathrm{~km}$ were considered (minimum length for the production of destructive earthquakes). 
It is reasonable to associate prehistoric earthquakes with specific faults because the data come from paleoseismological studies on the fault itself (Schwartz, 1988; Pantosti, 1997; Yeats et al., 1997; McCalpin, 2009). In the northwestern margin of the València trough, only the El Camp fault (see El Camp fault in section 4 for more information) as stated above and, specifically, the Hospitalet segment has been the subject of a paleoseismological study (Fig. 2).

To associate large historical earthquakes (I $\geq$ VIII) with known faults, Perea (2006 and 2009) and Perea et al. (2006) used the method proposed by Gasperini et al. (1999). This method assesses the location, physical dimensions, and orientation of the sources of large historical earthquakes on the bases of the distribution of their intensity data points. Assuming that no other causes apart from the source geometry are responsible for the distribution of damage, comparison of the results with mapped faults would allow us to determine the source fault of these earthquakes. This approach was applied to the following earthquakes: a) the I=IX, the 1396 Tavernes earthquake (Fontserè and Iglésies, 1971; López Marinas, 1982; Perea, 2006); b) the main earthquakes of the Catalan Seismic Crisis of 1427 and 1428, the Amer and Olot earthquakes, both with intensity VIII, and the I = IX Camprodon earthquake (Fontserè and Iglésies, 1971; Banda and Correig, 1984; Olivera et al., 1999; Olivera et al., 2006; Perea, 2006 and 2009; Perea et al., 2006); and c) the 1748 Énguera-Montesa earthquake with intensity IX or X (Fontserè and Iglésies, 1971; Bisbal, 1984; Albini, 2000; Perea, 2006). Only the first and second earthquakes of the Catalan Seismic Crisis, the Amer and Olot earthquakes (Fig. 3), have been unequivocally associated with a fault (see Amer fault in section 4 for further information).

The approach adopted to relate instrumental seismicity to faults assumes that the location of a number of epicenters inside the map projection of a fault plain reveals

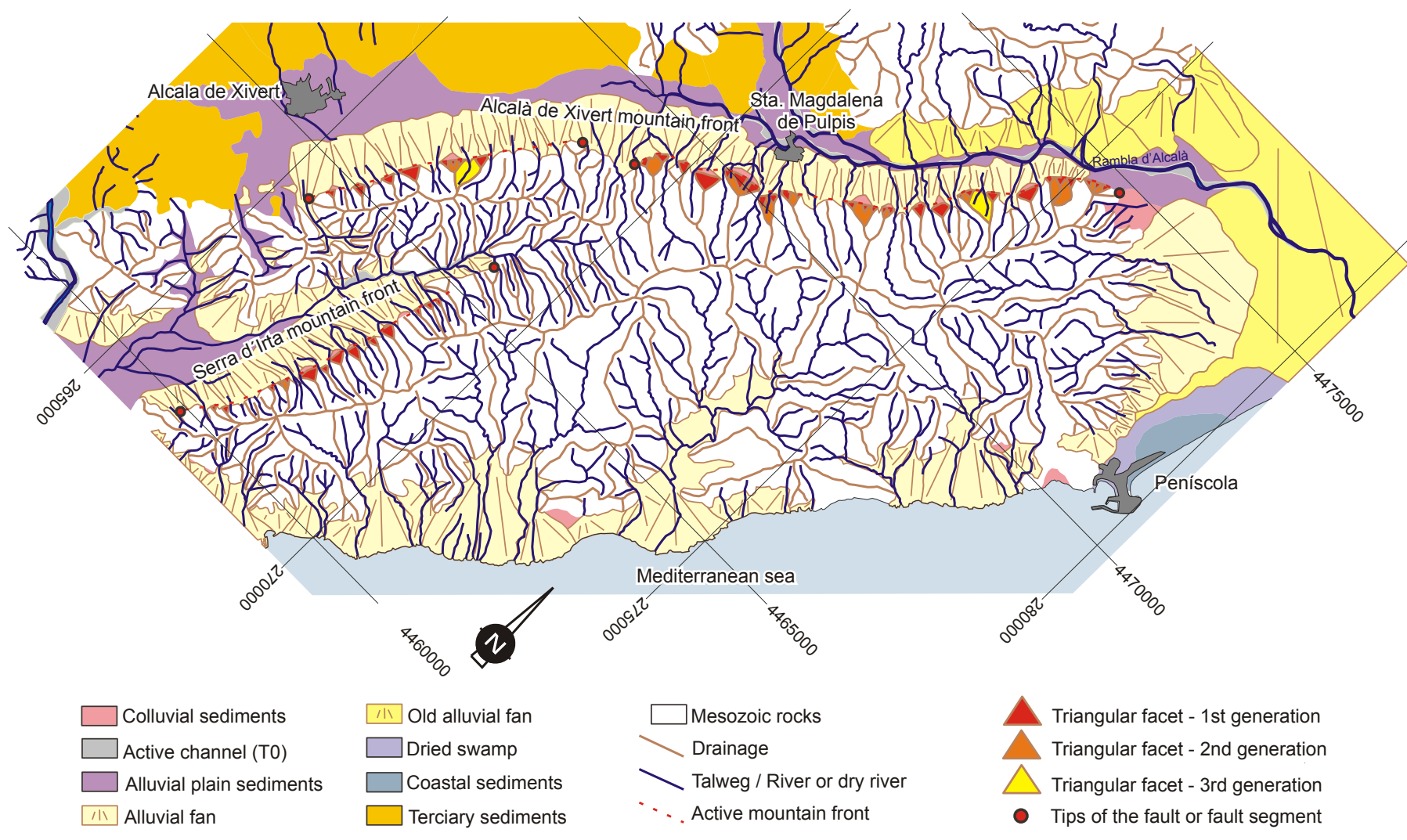

Fig. 5.- Geomorphological map of the Serra d'Irta range (modified from Perea, 2006). The Alcalà de Xivert and Serra d'Irta mountain fronts show gromorphologic features that point to the Plio-Quaternary activity of the faults with which they are associated (Perea, 2006; Perea $e t$ al., 2006). Note the presence of different generations of triangular facets and the low sinuosity of the front. The basins are wineglass shaped and regularly spaced (see section 4 and table 1 for further information and their location in Fig. 8)

Fig. 5.- Mapa geomorfológico de la Sierra de Irta (modificado de Perea, 2006). Los frentes de montaña de Alcalá de Xivert i de la Sierra de Irta muestran características geomorfológicas que indican una actividad Plio-Cuaternaria de las fallas a las cuales están asociados (Perea, 2006; Perea et al., 2006). Nótese la presencia de diferentes generaciones de facetas triangulares y la baja sinuosidad del frente. Las cuencas tienen forma de copa y muestran un espaciado regular (ver la sección 4 y la tabla 1 para más información y la figura 8 para su localización). 


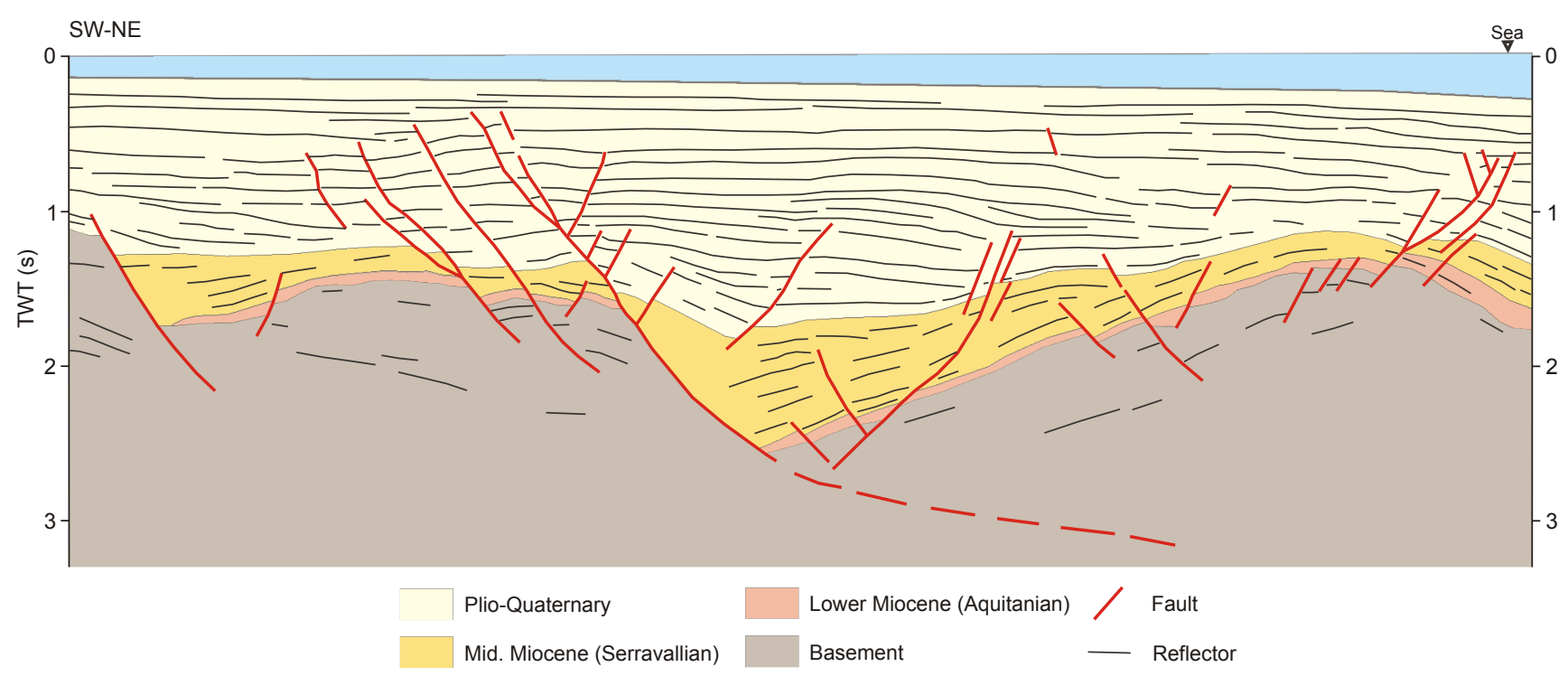

Fig. 6.- Cullera cape fault zone. Line drawing of the industrial reflection seismic profile GV-71 in the Cullera cape fault zone (modified from Roca, 1992). Note that the main normal faults offset the lower boundary of the Plio-Quaternary reflectors and that these faults show evidence of long term activity. See section 3.1 for more information about the approach and section 4 for the description of the fault zone. The location of the faults is in Fig. 8 and their parameters are in table 1.

Fig. 6.- Zona de falla del Cabo de Cullera. Interpretación del perfil de sísmica de reflexión con fines industriales GV-71 en la zona de falla del Cabo de Cullera (modificado de Roca, 1992). Nótese que las fallas normales principales desplazan los reflectores localizados en la base de la unidad Plio-Cuaternaria y que estas fallas también muestran evidencias de una actividad de larga duración. Ver la sección 3.1 para más información sobre la aproximación utilizada y la sección 4 para la descripción de la zona de falla. La localización de las fallas se puede ver en la figura 8 y sus parámetros en la tabla 1 .

moderate activity on the main fault and/or on small faults closely related to it (Fig. 4). This suggests that the fault is still active and, because of its size, could be considered the source of future large earthquakes. Thirty-eight faults showing such a relationship to moderate seismicity have been identified in the study area (Perea, 2006; Perea et al., 2006).

To assess the accumulated activity on faults during the Plio-Quaternary two different approaches were adopted, depending on the onshore or offshore location of the faults. For onshore faults, it has been assumed that, in a given structural region with definite geological and climatic characteristics, the geomorphological and morphometric features (e.g. sinuosity, slope and height of triangular facets, spacing ratio, valley floor-valley height ratio) of the mountain fronts associated with potentially active faults are similar to those shown by the fronts related to faults that have produced destructive earthquakes (Hamblin, 1976; Bull and McFadden, 1977; Wallace, 1978; Keller and Pinter, 1996; Burbank and Anderson, 2001). Comparison of the geomorphological characteristics of the mountain fronts associated with the active and seismogenic El Camp (Masana, 1995) and Amer (Ferrer et al., 1999) faults with other mountain fronts related to faults yielded fourteen additional fronts showing similar features (Fig. 5). These fronts are therefore considered to be related to active faults (Perea, 2006; Perea et al., 2006).

In the offshore zones, the analysis of seismic reflection profiles, usually of low resolution and high penetration acquired by oil companies, allowed the detection of faults that displace reflectors corresponding to the Plio-Quaternary (Fig. 6). Nine faults offsetting the Plio-Quaternary were located in the northwestern margin of the València trough area: one fault in the Gulf of Roses graben, three in the Amposta basin, four in the Cullera cape area and one in the Columbrets basin (Perea, 2006).

\subsection{Classification of active faults}

The extensional faults along the northwestern margin of the València trough were classified into five types (Fig. 7; Perea, 2006).

a) Faults with clear evidence of large paleo-, historical or instrumental earthquakes. These faults could also provide evidence of accumulated activity during the PlioQuaternary and/or could be associated with instrumental seismicity. Only two faults have been classified as belonging to this type: the Amer fault because it was the source of at least two large historical earthquakes (fault $\mathrm{n}^{\circ} 2$ in red 
Onshore faults

\begin{tabular}{|c|c|c|c|c|c|}
\hline Fault & $\begin{array}{l}\text { With large } \\
\text { earthquakes }\end{array}$ & $\begin{array}{l}\text { With Plio-Quaternary } \\
\text { activity and associated } \\
\text { instrumental seismicity }\end{array}$ & $\begin{array}{l}\text { With Plio-Quaternary } \\
\text { activity and without } \\
\text { associated } \\
\text { instrumental seismicity }\end{array}$ & $\begin{array}{c}\text { With associated } \\
\text { instrumental seismicity } \\
\text { and without } \\
\text { Plio-Quaternary activity }\end{array}$ & $\begin{array}{l}\text { Without evidence of } \\
\text { activity or inactive }\end{array}$ \\
\hline \multicolumn{6}{|c|}{$\begin{array}{l}\text { Instrumental } \\
\text { seismicity }\end{array}$} \\
\hline \multicolumn{6}{|c|}{$\begin{array}{l}\text { Large } \\
\text { earthquakes }\end{array}$} \\
\hline \multicolumn{6}{|c|}{$\begin{array}{l}\text { Mountain fronts } \\
\text { showing } \\
\text { recent activity }\end{array}$} \\
\hline Scheme & : & & It & e & $\left.\right|_{f_{(?)}}$ \\
\hline
\end{tabular}

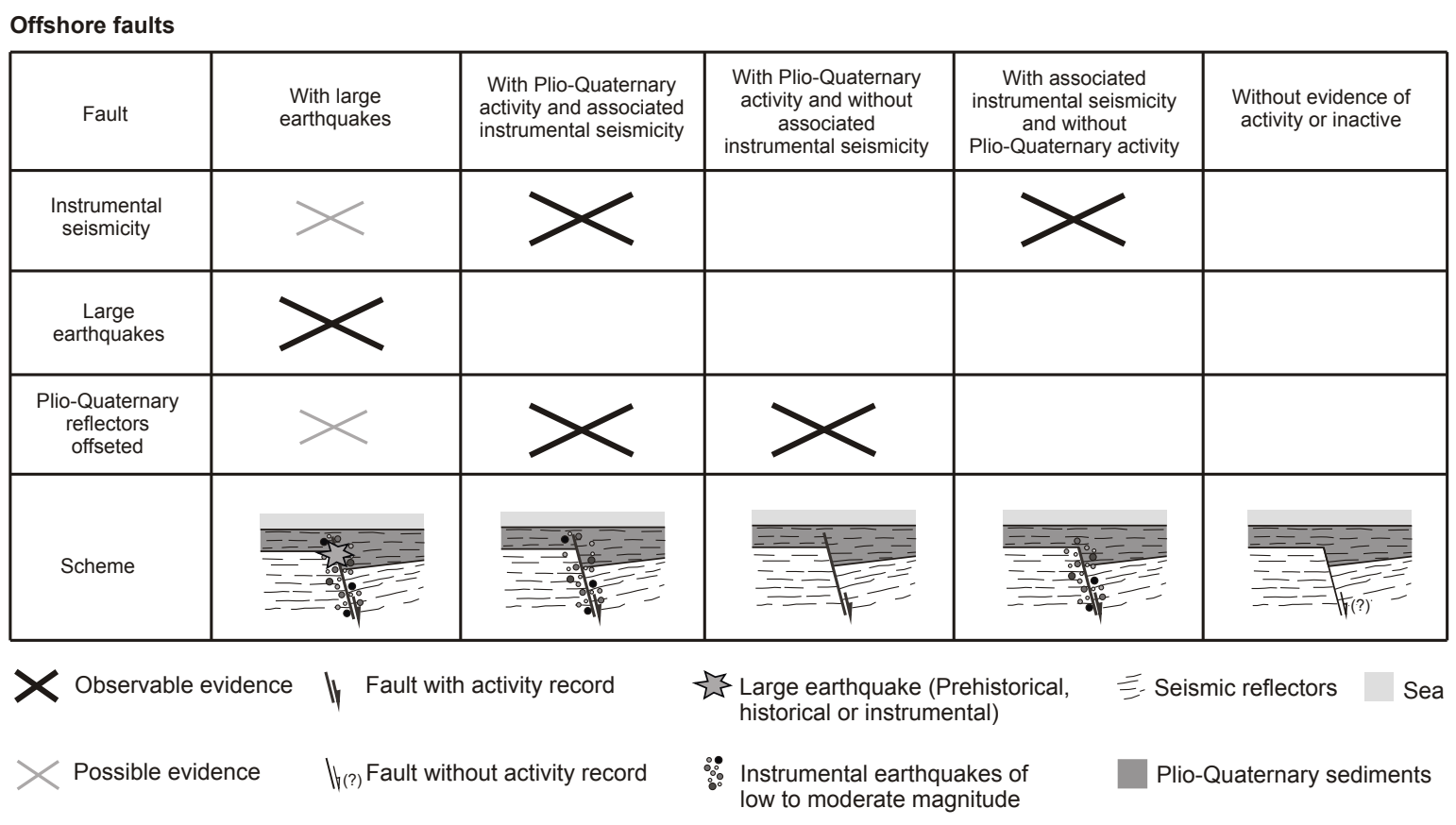

Fig. 7.- Classification of the normal faults located in the northwestern margin of the València trough (Perea, 2006). The cross symbols indicate observable (black bold) or possible observable (gray) evidence of Plio-Quaternary activity that characterizes each type of faults.

Fig. 7.- Clasificación de las fallas normales localizadas en el margen noroccidental del surco de Valencia (Perea, 2006). Las aspas indican la presencia de evidencias de actividad Plio-Cuaternaria observadas (negras gruesas) o posibles (gris) que caracterizan cada uno de los tipos de fallas descritos.

in Fig. 8 and section 4) and the Hospitalet segment of the El Camp fault because paleoseismological studies demonstrated that it has produced large earthquakes since the late Pleistocene (fault $\mathrm{n}^{\circ} 5$ in red in Fig. 8 and section 4).

b) Faults with evidence of accumulated activity during the Plio-Quaternary and with associated instrumental seismicity. Eight faults of the second type have been identified along the València trough (orange faults in Fig. 8).

c) Faults with evidence of accumulated activity during the Plio-Quaternary and without associated instrumental seismicity. Although these faults show no evidence of historical or instrumental seismic activity, they have been considered active because they show geomorphological features similar to those of the two confirmed seismogenic faults, one of which, the El Camp fault, shows no instrumental activity. The capability of these faults to produce large earthquakes in the future should therefore be taken into consideration. Seventeen faults of this type have been identified in the northwestern margin of the Valencia trough (yellow faults in Fig. 8).

d) Faults with associated instrumental seismicity and without evidence of accumulated activity during the Plio- 


\begin{tabular}{|c|c|c|c|c|c|c|c|c|c|}
\hline Fault & Segment & $\begin{array}{c}\text { Fault } \\
\text { length } \\
(\mathbf{k m})\end{array}$ & $\begin{array}{l}\text { Segment } \\
\text { length } \\
(\mathbf{k m})\end{array}$ & $\begin{array}{l}\text { Fault max. } \\
\text { magnitude } \\
\quad(\mathrm{Mw})\end{array}$ & $\begin{array}{l}\text { Segment } \\
\text { max. } \\
\text { magnitude } \\
(\mathrm{Mw})\end{array}$ & $\begin{array}{l}\text { Fault slip } \\
\text { rate } \\
(\mathrm{mm} / \mathbf{y r})\end{array}$ & $\begin{array}{c}\text { Segment slip } \\
\text { rate } \\
(\mathrm{mm} / \mathrm{yr})\end{array}$ & $\begin{array}{c}\text { Fault } \\
\text { recurrence } \\
\text { interval (years) }\end{array}$ & $\begin{array}{l}\text { Segment } \\
\text { recurrence } \\
\text { interval } \\
\text { (years) }\end{array}$ \\
\hline 1. Gulf of Roses & & 76.0 & & 7.3 & & $0.03-0.07$ & & 99976-39990 & \\
\hline \multirow[t]{2}{*}{ 2. Amer } & Northern & 35.4 & 19.3 & 6.9 & 6.6 & $0.06-0.14$ & $0.06-0.14$ & $27910-11164$ & $18146-7258$ \\
\hline & Southern & & 16.1 & & 6.5 & & $0.05-0.11$ & & $18796-7518$ \\
\hline 3. Montseny & & 23.1 & & 6.7 & & $0.04-0.11$ & & $26275-10510$ & \\
\hline 4. Pla de Barcelona & & 25.0 & & 6.7 & & $0.02-0.04$ & & 72494-28997 & \\
\hline \multirow[t]{3}{*}{ 5. El Camp } & Vilavella & 41.1 & 13.9 & 7.0 & 6.4 & $0.02-0.06$ & $0.02-0.05$ & $77767-31107$ & $38672-15469$ \\
\hline & La Selva & & 9.7 & & 6.2 & & $0.02-0.06$ & & $20766-8307$ \\
\hline & Hospitalet * & & 17.5 & & 6.5 & & $0.02-0.08$ & & $50000-25000$ \\
\hline 6. Pla de Burgar & & 14.2 & & 6.4 & & $0.02-0.05$ & & $37729-15091$ & \\
\hline \multirow[t]{6}{*}{ 7. Baix Ebre } & Xalamera-Cunca & 80.0 & 11.0 & 7.4 & 6.2 & $0.06-0.15$ & $0.06-0.15$ & $63620-25448$ & $7345-2938$ \\
\hline & Caramella & & 21.9 & & 6.6 & & $0.03-0.08$ & & $27485-10994$ \\
\hline & Sénia north & & 10.9 & & 6.2 & & $0.02-0.05$ & & $22151-8860$ \\
\hline & Sénia south & & 10.9 & & 6.2 & & $0.03-0.07$ & & $15822-6329$ \\
\hline & Tírig north & & 11.5 & & 6.3 & & $0.03-0.07$ & & $22012-8805$ \\
\hline & Tírig south & & 8.6 & & 6.1 & & $0.04-0.11$ & & $9041-3617$ \\
\hline 8. Montsià & & 11.0 & & 6.2 & & $0.03-0.09$ & & $14216-5686$ & \\
\hline 9. Western Amposta basin & & 18.0 & & 6.5 & & $0.01-0.03$ & & $72084-28833$ & \\
\hline 10. Central Amposta basin & & 35.0 & & 6.9 & & $0.01-0.03$ & & $135946-54378$ & \\
\hline 11. Eastern Amposta basin & & 51.0 & & 7.1 & & $0.04-0.10$ & & $55063-22025$ & \\
\hline \multirow[t]{2}{*}{ 12. Alcalà de Xivert } & Northern & 14.5 & 8.8 & 6.4 & 6.1 & $0.03-0.07$ & $0.02-0.05$ & $24651-9861$ & $18570-7428$ \\
\hline & Southern & & 4.8 & & 5.8 & & $0.03-0.07$ & & 9385-3754 \\
\hline 13. Irta range & & 5.9 & & 5.9 & & $0.02-0.06$ & & $13239-5296$ & \\
\hline \multirow[t]{3}{*}{ 14. Salzedella } & Northern & 23.5 & 5.8 & 6.7 & 5.9 & $0.02-0.04$ & $0.02-0.04$ & $68051-27220$ & $17476-6990$ \\
\hline & Central & & 9.5 & & 6.2 & & $0.01-0.04$ & & $36468-14587$ \\
\hline & Southern & & 8.0 & & 6.1 & & $0.02-0.04$ & & 28636-11454 \\
\hline 15. Vall d'Àngel & & 8.5 & & 6.1 & & $0.02-0.05$ & & $20162-8065$ & \\
\hline \multirow[t]{3}{*}{ 16. Albocàsser } & Northern & 20.4 & 5.0 & 6.6 & 5.8 & $0.05-0.12$ & $0.03-0.07$ & $19673-7869$ & $9298-3719$ \\
\hline & Central & & 6.0 & & 5.9 & & 0.03-0.09 & & $8402-3361$ \\
\hline & Southern & & 8.5 & & 6.1 & & $0.05-0.14$ & & $7467-2987$ \\
\hline \multirow[t]{2}{*}{ 17. Ivarsos } & Northern & 15.2 & 8.2 & 6.4 & 6.1 & $0.05-0.14$ & $0.05-0.14$ & $11763-4705$ & $7730-3092$ \\
\hline & Southern & & 6.8 & & 6.0 & $0.01-0.03$ & $0.02-0.04$ & & 20919-8368 \\
\hline \multirow[t]{2}{*}{ 18. Catí } & Northern & 19.0 & 6.0 & 6.5 & 5.9 & $0.05-0.11$ & $0.03-0.08$ & $15939-6376$ & $9522-3809$ \\
\hline & Southern & & 12.5 & & 6.3 & & $0.05-0.11$ & & $12168-4867$ \\
\hline \multirow[t]{2}{*}{ 19. Eastern Atzeneta } & Northern & 18.0 & 11.2 & 6.5 & 6.2 & 0.03-0.09 & 0.04-0.09 & $22317-8927$ & $12331-4933$ \\
\hline & Southern & & 6.5 & & 5.9 & & $0.03-0.08$ & & $8038-3215$ \\
\hline 20. Western Atzeneta & & 9.5 & & 6.2 & & $0.03-0.07$ & & $19636-7855$ & \\
\hline 21. Vall d’Uixó & & 6.6 & & 5.9 & & $0.01-0.03$ & & $20046-8018$ & \\
\hline 22. Western Cullera cape & & 28.0 & & 6.8 & & $0.02-0.05$ & & $69703-27881$ & \\
\hline 23. Central-west. Cullera cape & & 25.0 & & 6.7 & & $0.03-0.08$ & & $35239-14095$ & \\
\hline 24. Central-east. Cullera cape & & 48.0 & & 7.1 & & $0.01-0.03$ & & $175653-70261$ & \\
\hline 25. Eastern Cullera cape & & 16.0 & & 6.4 & & $0.01-0.02$ & & $70363-28145$ & \\
\hline 26. SW Columbrets basin & & 10.0 & & 6.2 & & $0.01-0.03$ & & $43881-17552$ & \\
\hline
\end{tabular}

* Seismic parameters of the segment coming from paleoseismological data

Table 1.- Seismic parameters corresponding to the active faults located in the northwestern margin of the València trough (modified from Perea, 2006 and Perea et al., 2006). Note that the seismic parameters correspond to faults and fault segments that have been classified as "faults with clear evidence of large paleo-, historic or instrumental earthquakes and as faults with evidence of accumulated activity during the Plio- Quaternary and with or without associated instrumental seismicity. The geographical location of the faults, identified by the same numbers, is given in Fig. 8 and they are described in the text.

Tabla 1.- Parámetros sísmicos correspondientes a las fallas activas localizadas en el margen noroccidental del surco de Valencia (modificado de Perea, 2006 y Perea et al., 2006). Nótese que los parámetros sísmicos correspondien a las fallas y segmentos de fallas clasificadas como fallas con claras evidencias de paleoterremotos o terremotos históricos o instrumentales, como fallas con evidencias de actividad acumulada durante el Plio-cuaternario y con asociación de terremotos instrumentales y como fallas con evidencias de actividad acumulada durante el Plio-cuaternario y sin asociación de terremotos instrumentales. La localización geográfica de las fallas, identificadas con el mismo número, se encuentra en la figura 8 y se describen en la sección 4 del texto.

Quaternary. Thirty faults have been classified as belonging to this type (green faults in Fig. 8). These faults would only be responsible for the low to moderate instrumental seismicity around them but, because of their dimensions, they could also give rise to large events. e) Faults without evidence of activity (inactive faults). These faults have been considered inactive despite trending approximately perpendicular to the current direction of extension. Thus, one hundred eighty-seven faults are inactive (gray faults in Fig. 8). 


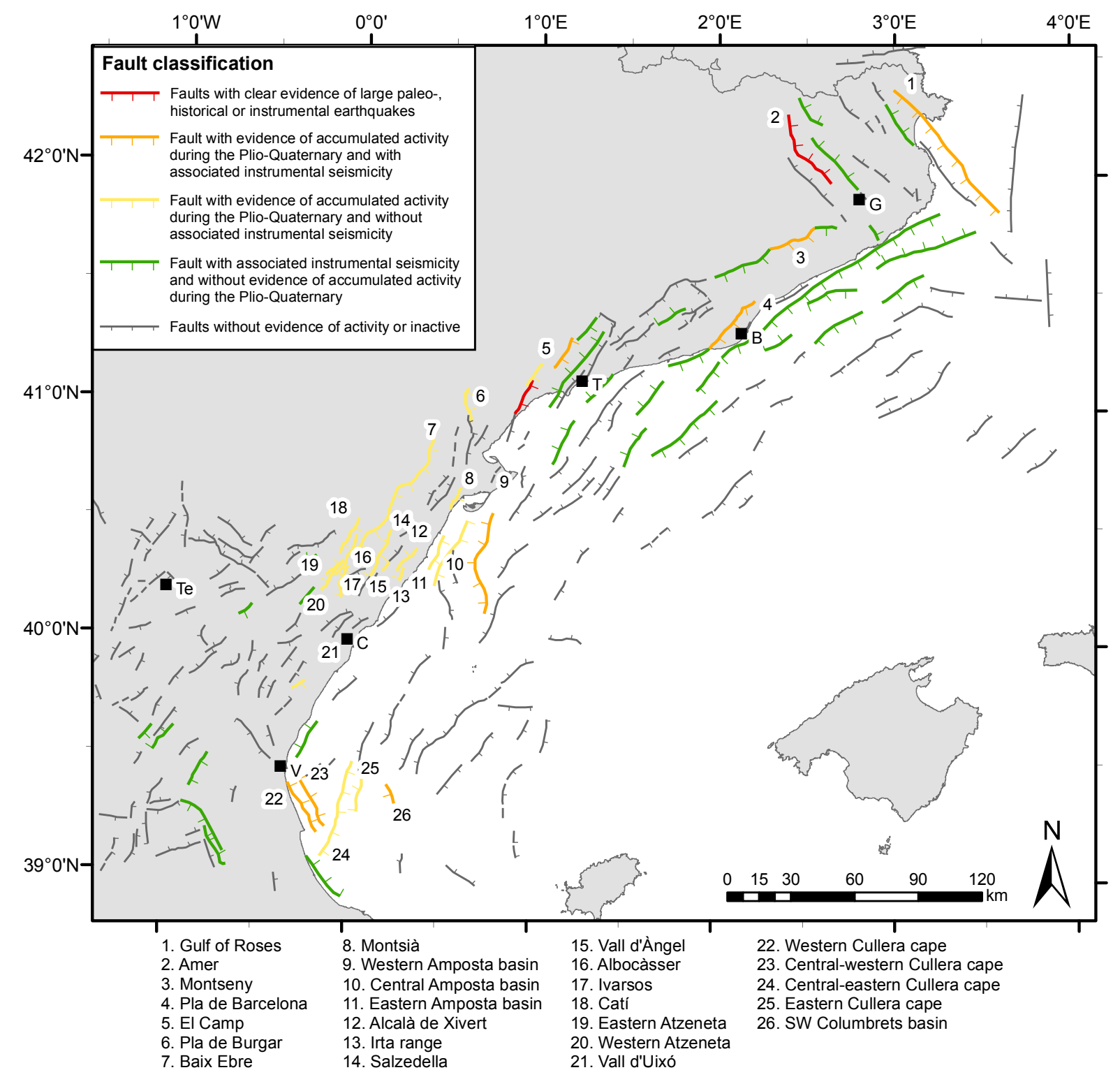

Fig. 8.- Map (modified from Perea et al., 2006) showing the location of the faults corresponding to each of the different types of active faults (Fig. 7): a) faults with clear evidence of large paleo-, historic or instrumental earthquakes (red lines); b) faults with evidence of accumulated activity during the Plio-Quaternary and with associated instrumental seismicity (orange lines); c) faults with evidence of accumulated activity during the Plio-Quaternary and without associated instrumental seismicity (yellow lines); d) faults with associated instrumental seismicity and without evidence of accumulated activity during the Plio-Quaternary (green lines), and e) faults without evidence of activity or inactive faults (gray lines). B: Barcelona; C: Castelló; G: Girona; T: Tarragona; Te: Teruel; V: València. The seismic parameters of the numbered faults and their description are given in table 1 and in the text, respectably.

Fig. 8.- Mapa (modificado de Perea et al., 2006) donde se muestra la localización de las fallas correspondientes a los distintos tipos de fallas activas (figura 7): a) fallas con claras evidencias de paleoterremotos o terremotos históricos o instrumentales (líneas rojas); b) fallas con evidencias de actividad acumulada durante el Plio-cuaternario y con asociación de terremotos instrumentales (líneas naranjas); c) fallas con evidencias de actividad acumulada durante el Plio-cuaternario y sin asociación de terremotos instrumentales (líneas amarillas); d) fallas con asociación de terremotos instrumentales y sin evidencias de actividad acumulada durante el Plio-cuaternario (líneas verdes); y e) fallas sin evidencias de actividad o inactivas (líneas grises). B: Barcelona; C: Castellón; G: Gerona; T: Tarragona; Te: Teruel; V: Valencia. Los parámetros sísmicos de las fallas y su descripción se encuentran en la tabla 1 y en el texto respectivamente..

\subsection{Evaluation of the seismic parameters of active faults}

In order to include the active faults in time dependent seismic hazard studies, it is necessary to have knowledge of the parameters that describe the seismic cycle of each fault in addition to information about geometry and kinematics. These parameters give us an idea of how tectonic stress is accumulated and released, i.e. the size and frequency of the seismic events. As a simplification, it is generally assumed that large earthquakes produced by 
the same fault are always identical in terms of rupture length and offset in accordance with the characteristic earthquake model (Schwartz and Coppersmith, 1984), and that they recur in line with the perfect periodic model (Reid, 1910). Accordingly, the parameters that describe this type of seismic cycle are a) the maximum magnitude earthquake, b) the recurrence interval of this earthquake and c) the time elapsed since the last earthquake.

Because of the long duration of the seismic cycle in slow deformation regions, the seismic parameters should be obtained from paleoseismological studies. Unfortunately, only the El Camp fault has been paleoseismologically studied in the València trough. Perea (2006) and Perea et al. (2006) proposed the following approach in order to compensate for the lack of paleoseismological information.

First, the maximum magnitude earthquake was calculated using the empirical relationships that relate magnitude to surface rupture length (Wells and Coppersmith, 1994). These authors assumed that the mapped length of the fault or fault segment corresponds to the maximum surface rupture length produced by the largest earthquake due to the fault.

Second, the recurrence interval was calculated using the relationship between seismic moment and moment rate proposed by Wesnousky (1986). The only unknown parameter is the fault slip rate given that the maximum magnitude of the earthquake and the dimensions (length and width) of the faults are known and the shear modulus is a constant $\left(3 * 10^{9} \mathrm{dyn} / \mathrm{cm}^{2}\right)$. In the case of onshore faults, the slip rate has been calculated considering the maximum topographic height of the youngest triangular facets as the fault minimum cumulative displacement since the Pliocene ( 2 to $5 \mathrm{Ma}$ ). In the northwestern margin of the València trough, the Pliocene age of the triangular facets has been established by comparison with the facets observed at the mountain front associated with the Tet-Cerdanya fault (Briais et al., 1990). The age of these facets is fairly well constrained from correlation with the stratigraphic units defined in the Cerdanya basin (Agustí and Roca, 1987; Cabrera et al., 1988). In the case of offshore faults, the slip rate has been obtained by measuring the offset at the base of the most recent formation which is Plio-Quaternary (Roca, 1992; Roca et al., 1999b). Perea (2006) demonstrated that slip rates obtained for offshore faults are usually lower than those calculated for onshore faults. According to this author, this is because the offset measured at the point where the seismic profile cuts the fault does not necessarily coincide with the maximum offset of the fault. This slip rate should therefore be considered as a minimum. Using these approaches, it is not possible to calculate the slip rate for faults only as- sociated with instrumental seismicity.

Finally, the time elapsed since the last event can only be obtained from the knowledge of the last earthquake, prehistoric, historical or instrumental. In the northwestern margin of the València trough, this information has only been obtained for the Amer and El Camp faults. For the rest of the faults, identified as active, this parameter has not been reported. However, this does not imply that they cannot be used in seismic hazard studies when the other parameters are known. To compensate for this lack of information, some studies have introduced different percentages of the recurrence interval as elapsed time (Ojeda et al., 2002; Perea, 2006; Perea and Atakan, 2007).

Despite the different approaches used to estimate the seismic parameters of active faults, it has only been possible to calculate them for 26 out of the 56 identified as active faults in the northwestern margin of the València trough, i.e. those classified as "faults with clear evidence of large paleo-, historic or instrumental earthquakes", "faults with evidence of accumulated activity during the PlioQuaternary and with associated instrumental seismicity" and "faults with evidence of accumulated activity during the Plio-Quaternary and without associated instrumental seismicity" (Perea, 2006; Perea et al., 2006). For the "faults with associated instrumental seismicity and without evidence of accumulated activity during the Plio-Quaternary" only the maximum earthquake can be estimated.

Finally, because of the simplicity of the approaches adopted to identify, classify and characterize the seismic cycle of active faults and because of the widely available information, they can be applied to other areas that are also characterized by low slip faults.

\section{Active faults}

Below is a review of the main features of the 26 active faults in the València trough of which we have data about their seismic parameters (Fig. 8 and Table 1).

Gulf of Roses fault (fault $\mathrm{n}^{\circ} 1$ in Fig. 8 and Table 1). This fault has been mapped using a number of seismic refraction profiles (Roca, 1992; Roca et al., 1999b). It trends NW-SE, dips towards the SW and is $76 \mathrm{~km}$ long. The evidence of its recent activity has been recognized on Profile 80-R-502 (seismic survey 80-R conducted by SHELL in 1980; in Roca et al., 1999b), where the PlioQuaternary unit is affected by the fault and its base is offset $0.19 \mathrm{~s}$ TWTT, which corresponds approx. to $140 \mathrm{~m}$ if we consider a seismic wave propagation speed of 1500 $\mathrm{m} / \mathrm{s}$. Thus, the slip rate of the fault for this time period varies between 0.03 and $0.07 \mathrm{~mm} /$ year (Perea, 2006). Moreover, this fault is responsible for some of the instrumental seismic activity (Perea, 2006; Perea et al., 2006). 
Amer fault (northern and southern segments) (fault $\mathrm{n}^{\circ} 2$ in Fig. 8 and Table 1). This fault marks the western boundary of the Empordà basin normal faults system and offsets the southernmost folded Eocene rocks of the Pyrenees (Saula et al. 1996). It has a total length of $35 \mathrm{~km}$, and because of its abrupt change in direction can be divided into two segments: the northern and the southern segments. The northern segment trends NNW-SSE, dips towards the ENE and is $19 \mathrm{~km}$ long, whereas the southern segment trends NW-SE, dips to the NE and measures $16 \mathrm{~km}$ in length (Ferrer et al., 1999; Fleta et al., 2001, Perea, 2006; Perea et al., 2006). The mountain fronts associated with these two fault segments show low sinuosity and three generations of triangular facets. In general, the basins are wineglass shaped and regularly spaced. All these geomorphological features indicate that the fault has undergone recent long term activity (Ferrer et al., 1999). The normal fault system of the Empordà basin has accumulated $8.4 \mathrm{~km}$ of normal offset during the last 8 Ma (Saula et al., 1996). Accordingly, Lewis et al. (2000) give a long term slip rate of $1 \mathrm{~mm} / \mathrm{yr}$ for the whole fault system. In the case of the Amer fault, Saula et al. (1996) report 1000 to $1400 \mathrm{~m}$ of offset since the beginning of its formation, which is upper Pliocene to lower Pleistocene in accordance with their geodynamic model. Therefore, the fault slip rate for the last 2 Ma ranges between 0.5 and $0.7 \mathrm{~mm} /$ year. However, there is no sedimentary evidence to date the beginning of the formation of the fault because the zone has been affected by river incision since the sinking of the Empordà basin (upper Miocene). The fault slip rate varies between 0.05 and $0.14 \mathrm{~mm} /$ year and has been calculated on the assumption that the maximum height of the youngest triangular facets corresponds to the Plio-Quaternary fault offset, which is $275 \mathrm{~m}$ in the northern segment and $225 \mathrm{~m}$ in the southern one (Perea, 2006; Perea et al., 2006). The lower slip rates are preferred because they are comparable to those obtained from paleoseismological studies for the El Camp fault (Masana et al., 2001a, b) and because similar strain rates along the region are expected. The Amer fault has been regarded as the origin of some of the instrumental seismicity recorded in the area and as the source of at least two of the three large earthquakes of the 1427 and 1428 Catalan seismic crisis (Goula et al., 1992). The March 19th 1427 earthquake (Fig. 3a) has been associated with the southern segment of the fault and the May 15th 1427 earthquake (Fig. 3b) has been related to the northern segment (Perea, 2006 and 2009; Perea et al. 2006). Perea (2009) modelled the Coulomb failure stress transfer after each of these two earthquakes. According to this author, the earthquake on February 2nd 1428, the last and largest one of the crisis, could have been generated by the north- ernmost part of the northern segment of the Amer fault or a fault parallel and close to it. Recently, Font et al. (2008) and Zarroca et al. (2010) have demonstrated the presence of radon gas anomalies related to the southern segment of the fault, which could be linked to its current activity.

Montseny fault (fault $\mathrm{n}^{\circ} 3$ in Fig. 8 and Table 1). This fault is part of the fault system that bounds the Neogene Vallès-Penedès basin to the NW (Roca, 1992; Roca and Guimerà, 1992) between the towns of La Garriga and Breda (Masana, 1995). The upthrown wall is mainly formed by Paleozoic sedimentary and intrusive rocks of the Variscan basement, whereas the Vallès basin, on the downthrown block, is filled with up to $800 \mathrm{~m}$ of detritic sediments ranging from the lower Miocene to the Quaternary (Anadon et al., 1983). Nevertheless, the Quaternary deposits are very restricted because of the predominance of the incision processes in the basin. The Montseny fault has a NE-SW direction, dips to the SE and is about $23 \mathrm{~km}$ long. The mountain front related to this fault shows low sinuosity, two generations of triangular facets and convex topographic profiles through the crests. The basins are regularly spaced and incised. These geomorphological features indicate its long term activity (Masana, 1995). The cumulative Plio-Quaternary offset is $224 \mathrm{~m}$ given that the maximum height of the youngest triangular facets corresponds to this period, yielding a slip rate ranging between 0.04 and $0.11 \mathrm{~mm} /$ year (Perea, 2006; Perea et al., 2006). The Montseny fault has been considered responsible for an intensity VII earthquake (Fontboté, 1954) that affected the area close to Sant Celoni (north of Vallès-Penedès basin) on March 12th 1927 (Fontserè, 1927; Susagna and Goula, 1999). Moreover, some instrumental seismicity has also been associated with this fault (Perea, 2006; Perea et al., 2006).

Pla de Barcelona fault (fault $\mathrm{n}^{\circ} 4$ in Fig. 8 and Table 1). This fault bounds the Pla de Barcelona basin to the NW. On the upthrown wall, the Collserola and Garraf ranges are constituted by the Variscan basement and its Mesozoic cover, respectively. The basin located on the downthrown block is filled with Miocene to Quaternary sediments. The main Quaternary morpho-sedimentary units are the Besos delta, the alluvial fans of the Barcelona plain and the Llobregat delta from north to south. The Pla de Barcelona fault trends NE-SW (Roca, 1992; Roca and Guimerà, 1992), dips to the SE and is $25 \mathrm{~km}$ long. There is some evidence of the Plio-Quaternary activity of the fault. First, Ribera Faig (1945) published a section of faulted Quaternary deposits located at the foot of the mountain front associated with this fault. Second, the analysis of topographic maps of the Barcelona plain made during the second half of the XIX ${ }^{\text {th }}$ century for town planning purposes enabled us to locate a morpho- 


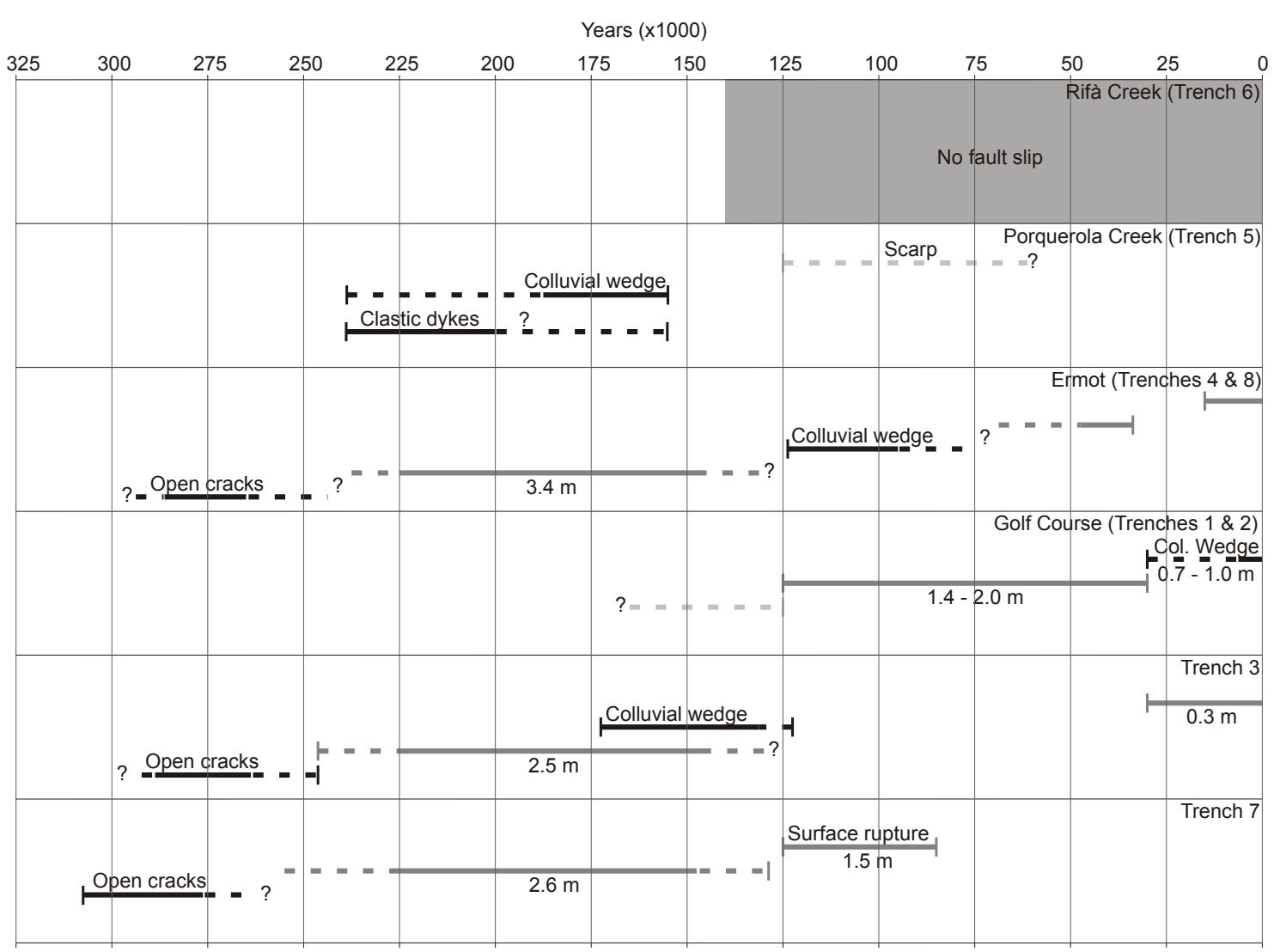

Fig. 9.- Synthesis of the paleoseismic history of the El Camp fault (Perea et al., 2006; Santanach et al., 2010). Black lines correspond to proved seismic events; dark gray lines to deformation events.

Fig. 9.- Síntesis de la historia paleosísmica de la falla de El Camp (Perea et al., 2006; Santanach et al., 2010). Las líneas de color negro corresponden a eventos sísmicos probados; las de color gris oscuro a eventos de deformación.

logical scarp crossing the plain. This scarp is located 2 $\mathrm{km}$ from the mountain front, trends parallel to it, and is about $14 \mathrm{~km}$ long. The study of geotechnical reports related to the construction of a new underground metro line suggests that the scarp could be associated with a fault that affects Quaternary sediments (Perea, 2006). Finally, the mountain front associated with the main fault shows one clear generation of triangular facets and slightly convex topographic profiles through the crests. The basins are wineglass shaped, regularly spaced and incised. All these geomorphological features suggest long term activity of the fault (Perea, 2006; Perea et al., 2006). Given the maximum height of the triangular facets, the accumulated Plio-Quaternary offset is $75 \mathrm{~m}$. Therefore, the slip rate of the fault for this time period ranges between 0.02 and $0.04 \mathrm{~mm} /$ year. The Pla de Barcelona fault is responsible for instrumental small magnitude earthquakes (Perea, 2006; Perea et al., 2006).

El Camp fault (La Selva, Vilavella and Hospitalet segments) (fault $\mathrm{n}^{\circ} 5$ in Fig. 8 and Table 1). This fault bounds the El Camp basin to the NW. On the upthrown wall, Variscan basement rocks and Mesozoic cover are exposed, and on the downthrown wall, a basin with 1400 to 2000 $\mathrm{m}$ of a lower Miocene to Quaternary infill is located (Nuñez et al., 1980; Medialdea et al., 1986). Quaternary alluvial fans extend from the mountain front, which is related to the fault, to the sea. Nevertheless, the fans along the Miramar segment (northern segment of the northern fault section) are restricted to the foot of the mountain front and overlie Neogene deposits (Masana, 1995).The El Camp fault has a NE-SW direction, dips to the SE (Roca, 1992; Roca and Guimerà, 1992) and is formed by two en echelon fault sections separated by a small right lateral step: the northern and the southern El Camp faults.

The northern El Camp fault is constituted by two segments. To the north, the Miramar segment is $15 \mathrm{~km}$ long and to the south, the La Selva segment is $13.9 \mathrm{~km}$. Of the two, only the La Selva segment provides evidence of PlioQuaternary activity. The mountain front associated with this segment has low sinuosity and three generations of triangular facets. The basins are wineglass shaped, regularly spaced and moderately to strongly incised. All these features suggest long term activity on the fault (Masana, 1995). The slip rate of the La Selva segment has been obtained on the assumption that the maximum height of the youngest triangular facets, $90 \mathrm{~m}$, is equivalent to the 
offset accumulated during the Plio-Quaternary. Thus, the slip rate of this fault segment for this time period varies between 0.02 and $0.06 \mathrm{~mm} /$ year (Perea, 2006, Perea et al., 2006). Both segments of the northern El Camp fault account for some of the instrumental seismicity in the vicinity (Perea, 2006, Perea et al., 2006).

The southern El Camp fault is composed of two segments: the Vilavella segment, which is $9.7 \mathrm{~km}$ long to the north, and the Hospitalet segment, which enters the sea to the south. The onshore length of this last segment is $17.5 \mathrm{~km}$ and extends $24 \mathrm{~km}$ when the offshore trace of the fault is considered. The mountain front associated with the southern El Camp fault shows geomorphological features similar to those described for the La Selva segment, which suggests its long term activity.

Despite the absence of instrumental seismicity in the surroundings of the southern El camp fault, liquefaction structures including clastic dikes formed by matrix supported conglomerates intruded upwards and colluvial wedges provide evidence of the seismic behavior of the Hospitalet segment (Masana et al., 2001a, b). This is also supported by the presence of a discontinuous scarp running parallel and close to the mountain front of the Hospitalet and Vilavella segments and affecting upper Pleistocene alluvial fans (Masana, 1995). The proximity of the fault to the Vandellós nuclear power plant prompted the "Consejo de Seguridad Nuclear" (Spanish nuclear security council) to undertake a paleoseismological study, the first such study in Spain (Santanach et al., 2001). This alluvial fan has been dated using different methods, such as $\mathrm{U} / \mathrm{Th}$, thermoluminescence, radiocarbon and pollen (Villamarín et al., 1999, Santanach et al. 2001), and a paleoseismological study has been carried out along this scarp, where eight trenches were dug and analyzed (Fig. 2).

The Hospitalet segment has produced at least six large earthquakes during the last $300 \mathrm{ka}$, three of which occurred in the last $125 \mathrm{ka}$. Figure 9 summarizes the main results obtained during the paleosismological study of the El Camp fault and shows the events per trench, the paleoseismic criteria, and the fault displacement. In the last $125 \mathrm{ka}$, the slip rate ranges between 0.02 and 0.08 $\mathrm{mm} /$ year, the lowest value being the most reasonable. The maximum magnitude earthquake is $6.7(\mathrm{Mw})$ with a recurrence interval of 30000 years (between 25.000 and 50.000 years) and the last event is dated at about 3000 years. North of the Rifà creek, beds dated at $140 \mathrm{ka}$ seal the fault, implying that this zone of the fault has not been active since that date (Masana, 1995 and 1996; Masana et al., 2001a and 2001b; Santanach et al., 2001; Perea et al., 2003; Perea, 2006; Perea et al., 2006; Santanach et al., 2010).
Perea (2006) and Perea et al. (2006) calculated the slip rate of the two segments of the southern fault on the assumption that the accumulated offset during the PlioQuaternary was represented by the maximum height of the youngest triangular facets. These authors obtained rates ranging between 0.02 and $0.06 \mathrm{~mm} /$ year and demonstrated a good correlation between these rates and those derived from paleoseismological studies. Thus, they regarded as reasonable the slip rates calculated from the height of the triangular facets for the whole northwestern margin of the València trough.

Pla de Burgar fault (fault $\mathrm{n}^{\circ} 6$ in Fig. 8 and Table 1). The Pla de Burgar fault bounds the Plio-Quaternary Pla de Burgar basin to the west (Roca, 1992; Roca and Guimerà, 1992). Triassic and Jurassic carbonate rocks are exposed on the upthrown wall. The fault is N-S trending, eastward dipping and is $13 \mathrm{~km}$ long. The mountain front associated with the fault shows only one generation of triangular facets. Its maximum height is $90 \mathrm{~m}$ (Masana, 1995), the value assumed to be the Plio-Quaternary accumulated offset and used to calculate the slip rate, which varies between 0.02 and $0.05 \mathrm{~mm} / \mathrm{year}$ for this time period (Perea, 2006; Perea et al., 2006).

Baix Ebre fault (Xalamera-Cunca, Caramella, Sénia north, Sénia south, Tirig north and Tirig south segments) (fault $\mathrm{n}^{\circ} 7$ in Fig. 8 and Table 1). This fault has created a mountain front that bounds the Ports range (maximum height, Montcaro, $1434 \mathrm{~m}$ ), which is constituted mainly by carbonate Mesozoic rocks. At its foot, the Baix Ebre basin is filled with Miocene to Quaternary deposits that attain a thickness of up to $400 \mathrm{~m}$ (Arasa, 1994). The fault (Roca, 1992; Roca and Guimerà, 1992) trends NNE$\mathrm{SSW}$, dips to the SE and is $75 \mathrm{~km}$ long. It has been divided into seven segments on the basis of abrupt changes in direction, front step-overs, and different cumulative seismic behavior as evidenced by the geomorphological features. They are from north to south: Xalamera-Cunca (11 km long), Caramella (22 km long), Sènia north (11 $\mathrm{km}$ long), Sènia south (11 km long), Rossell-Xert (15 km long), Tírig north (11.5 km long) and Tírig south (8.6 km long). With the exception of the Rossell-Xert segment, the others display mountain fronts with, in general, low sinuosity, between two and three generations of triangular facets and convex topographic profiles through the crests. Generally, the basins are wineglass shaped, regularly spaced and slightly incised. All these geomorphological features indicate long term activity of these fault segments (Masana, 1995; Perea, 2006; Perea et al. 2006). The Plio-Quaternary displacement of these segments is assumed to be the height of the youngest triangular facets of each segment, which is $300 \mathrm{~m}, 160 \mathrm{~m}, 100 \mathrm{~m}, 140$ 
$\mathrm{m}, 135 \mathrm{~m}$ and $220 \mathrm{~m}$ from north to south. Therefore, the slip rate for this time period varies between 0.06-0.15, 0.03-0.08, 0.02-0.05, 0.03-0.07, 0.03-0.07 and 0.04-0.11 $\mathrm{mm} /$ year for each of these fault segments (Perea, 2006; Perea et al., 2006). In the absence of evidence for long term activity of the Rossell-Xert segment, Perea (2006) regards the segment as part of the whole fault in the most conservative models of seismic hazard estimation. Instrumental seismicity is not associated with any of the segments of the Baix Ebre fault.

Montsià fault (fault $\mathrm{n}^{\circ} 8$ in Fig. 8 and Table 1). The Montisà range is constituted by Mesozoic sedimentary rocks. The basin, located on the eastern side of the range, extends offshore and is filled with sediments ranging from the late Miocene to the Quaternary, with a maximum thickness of $140 \mathrm{~m}$ close to the front (Arasa, 1994). The eastern mountain front of the Montsià range is associated with a NE-SW trending fault (Roca, 1992; Roca and Guimerà, 1992), which dips to the $\mathrm{SE}$ and is $11 \mathrm{~km}$ long. This mountain front displays three generations of triangular facets and basins that are wineglass shaped and regularly spaced. All these geomorphological features point to long term activity of the fault. Furthermore, there is a scarp that runs parallel to the mountain front across Quaternary alluvial fans. This scarp, at its northern and southern terminations, branches into the front coinciding with the presence of small triangular facets. Moreover, a number of small alluvial fans have their apexes at the foot of the scarp. These observations suggest a tectonic origin of the scarp. The Plio-Quaternary slip rate was calculated using the maximum height of the youngest triangular facets, which is $155 \mathrm{~m}$, on the assumption that this height corresponds to the fault offset during this time period. Thus, the slip rate of the fault varies between 0.03 and $0.09 \mathrm{~mm} /$ year (Perea, 2006; Perea et al., 2006).

Amposta basin faults (western, central and eastern faults) (faults $n^{\circ}$ 9, 10 and 11 in Fig. 8 and Table 1). The Amposta basin is located south of the Ebro delta and is bounded by a number of extensive Neogene faults with an approximately N-S direction (Roca, 1992; Roca and Guimerà, 1992). The seismic reflection profile 780-030 (seismic survey 780 conducted by SHELL in 1978; in Roca, 1992) shows that several normal faults displace the base of the Plio-Quaternary unit, three of which offset reflectors very close to the surface. These are the western, central and eastern faults. The western fault, which is 18 $\mathrm{km}$ long, dips towards the $\mathrm{E}$ and displaces the base of the Plio-Quaternary $0.07 \mathrm{~s}$ TWTT, which is equivalent to 53 $\mathrm{m}$ (seismic waves speed propagation $=1500 \mathrm{~m} / \mathrm{s}$ ). The central fault, which is $35 \mathrm{~km}$ long, dips to the E and offsets the base of the Plio-Quaternary 0.08 s TWTT, which corresponds to $57 \mathrm{~m}$. The eastern fault, which is $51 \mathrm{~km}$ long, dips towards the $\mathrm{W}$ and causes an offset at the base of the Plio-Quaternary of $0.26 \mathrm{~s}$ TWTT, which is equivalent to $193 \mathrm{~m}$. Thus, the slip rate of the faults for the PlioQuaternary ranges, from west to east, between 0.01-0.03, 0.01-0.03 and 0.04-0.10 mm/year. Instrumental seismicity is also associated with the eastern fault (Perea, 2006; Perea et al., 2006).

Irta range faults (Alcalà de Xivert fault, northern and southern segments, and Irta range fault) (faults $\mathrm{n}^{\circ} 12$ and 13 in Fig. 8 and Table 1). The Irta range is a small mountain range that is elongated in a NE-SW direction (Fig. 5). It exposes Mesozoic carbonate rocks and the basins are filled with Neogene and Quaternary detritic sediments (Simón et al., 1983; Simón, 1984; Moissenet, 1989). The western front of the range is bounded by two normal faults that dip towards the NW, the $14.5 \mathrm{~km}$ long Alcala de Xivert fault and the Irta range fault, which is approximately $6 \mathrm{~km}$ long (Simón et al., 1983; Simón, 1984; Roca, 1992; Roca and Guimerà, 1992). On the A1calà de Xivert fault, the presence of a mountain front step over and a small change in direction enabled us to distinguish two segments: the northern (almost $9 \mathrm{~km}$ long) and the southern ( $5 \mathrm{~km}$ long). The mountain fronts associated with both faults show low sinuosity, two to three generations of triangular facets and convex topographic profiles through the crest. The basins are wineglass shaped, regularly spaced and incised. All these features point to the long term activity of the Alcalà de Xivert and Irta range faults. To calculate the Plio-Quaternary fault slip rate, the maximum height of the youngest triangular facets has been used. The heights corresponding to the northern and southern segments of the Alcalà de Xivert fault are $105 \mathrm{~m}$ and $135 \mathrm{~m}$ and the height of the Irta range fault is $110 \mathrm{~m}$. Thus, the slip rate of the faults for this time period varies between 0.02-0.05, 0.03-0.07 and 0.02-0.06 mm/year, respectively(Perea, 2006; Perea et al., 2006).

Vall d'Angel range faults (the Salzedella fault, northern, central and southern segments, and the Vall d'Angel fault) (faults $n^{\circ} 14$ and 15 in Fig. 8 and Table 1). The Vall d'Àngel range has a NE-SW direction and is formed mainly by Mesozoic detritic and carbonate rocks. The western boundary of the Vall d'Àngel range is controlled by the Salzedella fault (Simón et al., 1983; Simón, 1984; Moissenet, 1989; Roca, 1992; Roca and Guimerà, 1992). A basin filled with up to $245 \mathrm{~m}$ of lower Miocene to Quaternary detritic deposits is located on its downthrown block (Arasa, 1994). The Quaternary units mainly consist of alluvial fans and fluvial terraces that totally cover the northern part of the basin (Simón, 1984; Perea, 2006), whereas to the south, their extent is restricted and Miocene units are exposed. The Salzedella fault trends NE-SW, dips towards the NW and is $23.5 \mathrm{~km}$ long. The 
presence of two step-overs on the mountain front enabled us to define three segments, the northern, central and southern, $6 \mathrm{~km}, 9.5 \mathrm{~km}$ and $8 \mathrm{~km}$ long, respectively. The geomorphological features of the mountain front along the three segments are similar and show low sinuosity, two generations of triangular facets (an uncertain third generation on the southern segment) and slightly convex topographic profiles through the crests. The basins are wineglass shaped and regularly spaced. All these features provide evidence of long term activity of the whole fault. The Plio-Quaternary slip rate has been calculated, considering the maximum height of the youngest triangular facets as the accumulated displacement during this time range. These heights are 85,70 and $75 \mathrm{~m}$ for the northern, central and southern segments, respectively, and the corresponding slip rates varies between 0.02-0.04, 0.01-0.04 and 0.02-0.04 mm/year (Perea, 2006; Perea et al., 2006). Miocene and Quaternary detritic sediments infill the Vall d'Àngel basin located in the central-southern part of the range. This small sedimentary basin trends in the same direction as the range and is controlled by the Vall d'Àngel fault located along its eastern margin (Simón et al., 1983; Simón, 1984; Moissenet, 1989; Roca, 1992; Roca and Guimerà, 1992). The Quaternary units consist of small alluvial fans with the source zone located in the upthrown block of the fault. This fault is $8.5 \mathrm{~km}$ long and dips to the NW. The mountain front related to the fault shows low sinuosity, three generations of triangular facets and slightly convex topographic profiles through the crests. The basins are wineglass shaped, regularly spaced and incised. All geomorphological features point to long term activity of the fault. The height of the youngest facets is $100 \mathrm{~m}$ and has been used to calculate the Plio-Quaternary slip rate. Thus, the slip rate of the fault varies between 0.02 and $0.05 \mathrm{~mm} /$ year (Perea, 2006; Perea et al., 2006).

Albocàsser basin faults (Albocàsser fault, northern, central and southern segments, and Ivarsos fault, northern and southern segments) (faults $\mathrm{n}^{\circ} 16$ and 17 in Fig. 8 and Table 1). The Albocàsser basin is a NNE-SSW depression almost completely covered by Quaternary alluvial fans. Notwithstanding, lower Miocene sediments are exposed towards the southeast of the village of Ivarsos, and upper Miocene sediments are located around the village of Albocàsser. The Albocàsser basin is bounded by the Albocàsser fault to the northeast and by the Ivarsos fault to the southwest (Simón et al., 1983; Simón, 1984; Moissenet, 1989; Roca, 1992; Roca and Guimerà, 1992). The mountain fronts associated with both faults expose Mesozoic carbonate rocks.

The Albocàsser fault is ca. $20 \mathrm{~km}$ long and dips to the SE. A topographic height and a small change in direction enabled us to distinguish between the northern and central segments, and a step over separates the central segment from the southern one. The segments are $5 \mathrm{~km}, 6 \mathrm{~km}$ and $8.5 \mathrm{~km}$ long, from north to south. The mountain fronts associated with these segments show low sinuosity, two generations of triangular facets in the northern and central segments and three generations in the southern one, and slightly convex topographic profiles through the crests. The basins are generally wineglass shaped, regularly spaced and incised. All these features reveal long term activity of the different fault segments. The height of youngest triangular facets is 130, 170 and $240 \mathrm{~m}$ for the northern, central and southern segments, respectively, and has been considered as the cumulative Plio-Quaternary displacement. Thus, the slip rate of these segments varies between 0.03-0.07, 0.03-0.09 and 0.05-0.14 $\mathrm{mm} /$ year from north to south (Perea, 2006; Perea et al., 2006).

The Ivarsos fault is $15 \mathrm{~km}$ long and dips towards the NW. The presence of a step over and a change in direction of the mountain front allowed us to define two segments: the northern and southern segments. The northern segment is $8 \mathrm{~km}$ long and the southern one is almost 7 $\mathrm{km}$. The long term activity of these segments is revealed by their geomorphological features. The mountain front shows low sinuosity, two generations of triangular facets and slightly convex topographic profiles through the crests. Furthermore, the basins are wineglass shaped, regularly spaced and incised. The Plio-Quaternary slip rate was calculated from the maximum height of the youngest triangular facets, which is 270 and $85 \mathrm{~m}$ for the northern and southern segments, respectively. Therefore, the slip rate of the two segments varies between 0.05-0.14 and 0.02-0.04 mm/year (Perea, 2006; Perea et al., 2006).

Cati fault (northern and southern segments) (fault $\mathrm{n}^{\mathrm{o}} 18$ in Fig. 8 and Table 1). The Catí basin is covered by Quaternary detritic sediments, mainly alluvial fans that are slightly incised (Simón, 1984; Perea, 2006). To the northwest, the basin is bounded by a NE-SW oriented mountain front where Mesozoic carbonate rocks are exposed. This front is associated with the Catí fault, which is $20 \mathrm{~km}$ long and dips to the SE (Simón et al., 1983; Simón, 1984; Moissenet, 1989; Roca, 1992; Roca and Guimerà, 1992). A step over allowed us to distinguish two segments: the northern (6 km long) and the southern (12.5 km long). Furthermore, the long term activity of the segments of the Catí fault is evidenced by their geomorphological features. The mountain fronts show low sinuosity, two generations of triangular facets in the northern segment and three generations in the southern one, and slightly convex topographic profiles through the crests. The ba- 
sins are wineglass shaped, regularly spaced and incised. The maximum height of the youngest triangular facets, which is 150 and $225 \mathrm{~m}$ for the northern and southern segments, respectively, is assumed to be the accumulated offset during the Plio-Quaternary. Thus, the slip rate of these segments varies between 0.03-0.08 and 0.05-0.11 $\mathrm{mm} /$ year (Perea, 2006; Perea et al., 2006).

Atzeneta basin faults (eastern Atzeneta fault, northern and southern segments, and western Atzeneta fault). (faults $\mathrm{n}^{\circ} 19$ and 20 in Fig. 8 and Table 1) The Atzeneta basin extends in a NE-SW direction and is bounded by two ranges, the Espaneguera range to the east, which is related to the eastern Atzenera fault, and the Ensegur range to the west, which is partly associated with the western Atzeneta fault (Simón et al., 1983; Simón, 1984; Moissenet, 1989; Roca, 1992; Roca and Guimerà, 1992). The ranges are mainly made up of Mesozoic carbonate rocks, whereas the basin infill comprises sediments from the early Miocene, which crop out to the southeast of the basin, to the Quaternary.

The eastern Atzeneta fault is $18 \mathrm{~km}$ long and dips to the NW. Because of a step over, this fault can be divided into two segments: the northern one measuring almost 11 $\mathrm{km}$ in length and the southern one with a length of 6.5 $\mathrm{km}$. The mountain fronts associated with these segments show low sinuosity, three generations of triangular facets in the northern segment and two generations in the southern one, and slightly convex topographic profiles through the crests. The basins are wineglass shaped and regularly spaced. Thus, these segments provide evidence of long term activity. The Plio-Quaternary slip rate of the faults has been calculated from the maximum height of the youngest triangular facets, which is 175 and $165 \mathrm{~m}$ for the northern and southern segments, respectively. Accordingly, the slip rate of these segments varies between 0.04-0.09 and 0.03-0.08 mm/year (Perea, 2006; Perea et al., 2006).

The western Atzeneta fault is $9.5 \mathrm{~km}$ long and dips to the SW. Its associated mountain front displays low sinuosity and three generations of triangular facets. The basins are wineglass shaped, regularly spaced and slightly incised. These features provide evidence of long term fault activity. The maximum height of the youngest triangular facets is $130 \mathrm{~m}$, which is considered to be the Plio-Quaternary displacement of the fault. Therefore, the segment slip rate ranges between 0.03 and $0.07 \mathrm{~mm} /$ year (Perea, 2006; Perea et al., 2006).

Vall d'Uixó fault (fault $\mathrm{n}^{\circ} 21$ in Fig. 8 and Table 1). This fault is located along the southern front of the El Cid range, where Mesozoic detritic and carbonate rocks are exposed. It trends NE-SW, dips to the SE (Simón, 1984; Roca, 1992; Roca and Guimerà, 1992) and is 6.6 $\mathrm{km}$ long. The mountain front associated with this fault shows low sinuosity, two generations of triangular facets and convex topographic profiles through the crests. The basins are wineglass shaped and regularly spaced. All the geomorphological features provide evidence of long term fault activity. In addition, a scarp has been described close to the southern tip of the fault near and parallel to the mountain front. On the sides of the Bonell creek, a caliche that grew on a Quaternary alluvial fan is fractured and apparently displaced where this scarp should cross the creek (Perea, 2006). No detailed studies have been carried out to verify the association of the scarp with a fault to date. The Plio-Quaternary fault slip rate ranges between 0.01 and $0.03 \mathrm{~mm} /$ year and has been calculated by considering the maximum height of the youngest triangular facets, which is $65 \mathrm{~m}$, as the accumulated offset during this time. (Perea, 2006; Perea et al., 2006).

Cullera cape faults (western, central-western, centraleastern and eastern faults) (faults $\mathrm{n}^{\mathrm{o}} 22,23,24$ and 25 in Fig. 8 and Table 1). The Cullera cape is located to the south of the city of València. Between 5 and $30 \mathrm{~km}$ offshore opposite this cape a number of faults have been mapped based on seismic reflection profiles (Fig. 6). According to seismic profile GV-71 (seismic survey GV conducted by ENPASA in 1973; in Roca, 1992), these faults displace the reflectors from the base of the PlioQuaternary unit. Of these faults, four offset some reflectors located close to the surface, thereby suggesting that they could still be active. These faults are the western, central-western, central-eastern and eastern faults. The western and central-western faults trend NW-SE, dip to the NE and are $28 \mathrm{~km}$ and $25 \mathrm{~km}$ long, respectively. The central-eastern fault trends NE-SW, dips to the SE and is $48 \mathrm{~km}$ long. Finally, the eastern fault also trends NESW but dips to the NW and is $16 \mathrm{~km}$ long. The slip rate was calculated from the displacement of the base of the Plio-Quaternary unit. From west to east, the displacement is $0.13,0.21,0.09$ and $0.06 \mathrm{~s}$ TWTT, which corresponds to offsets of about 99, 154, 64 and $43 \mathrm{~m}$, respectively, assuming a propagation speed of the seismic waves of $1500 \mathrm{~m} / \mathrm{s}$. Thus, the slip rate of these faults varies between 0.02-0.05, 0.03-0.08, 0.01-0.03 and 0.01-0.02 mm/ year (Perea, 2006). The two western faults account for some of the instrumental seismicity that occurred in the area, providing evidence of their recent activity. It has been suggested (Perea, 2006) that one of these two faults could be the source of the 1396 Tavernes earthquake with an assigned intensity of IX (Fontserè and Iglésies, 1971; López Marinas, 1982) since it was probably generated by a fault located offshore.

South-western fault of the Columbrets basin (fault $\mathrm{n}^{\mathrm{o}} 26$ in Fig. 8 and Table 1). The NE-SW oriented Neogene Co- 


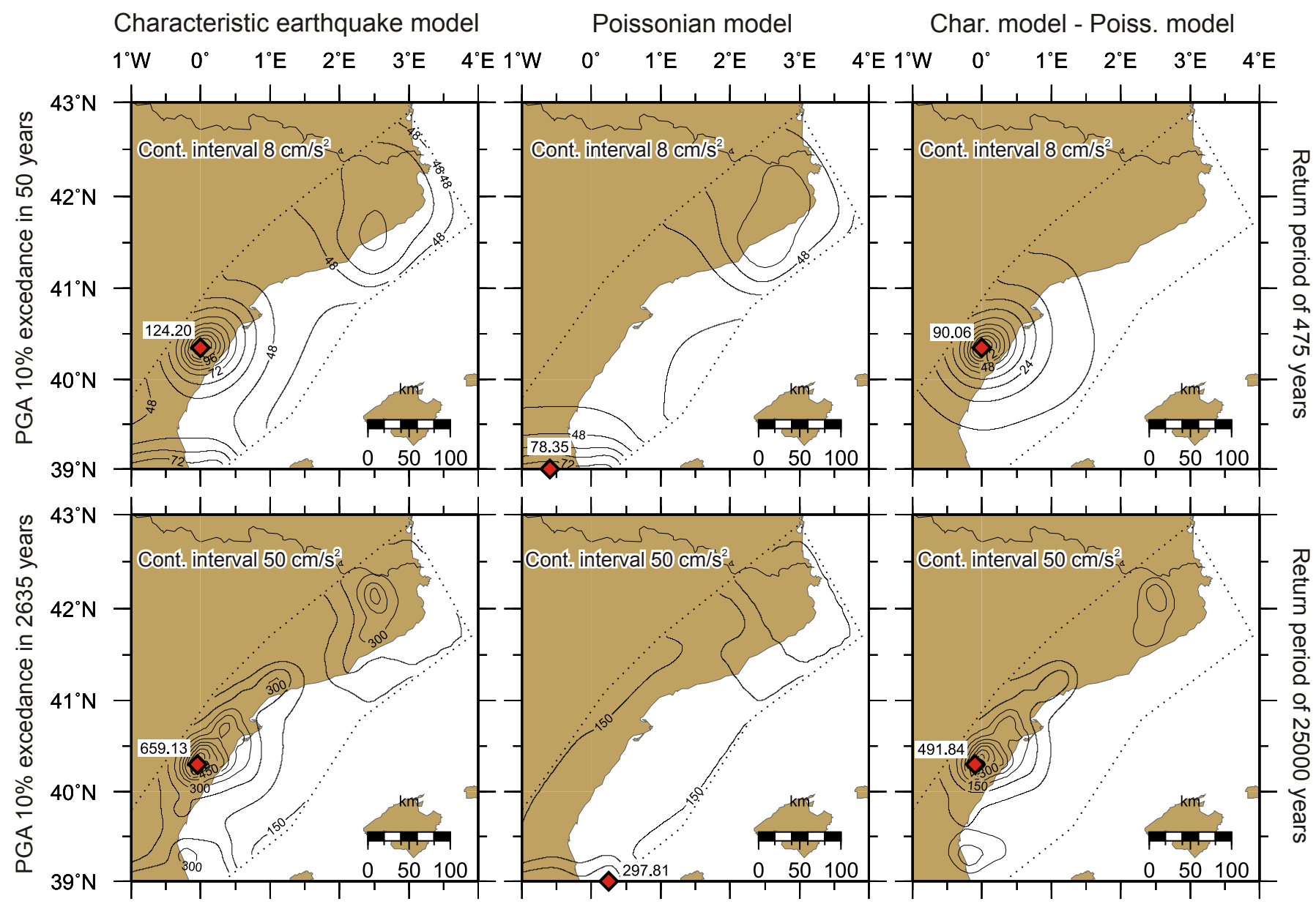

Fig. 10. Maps showing the PGA distribution (modified from Perea, 2006 and Perea and Atakan, 2007) corresponding to a model considering faults as time dependent sources (characteristic earthquake model column), a model without considering faults (poissonian model column) and the difference between both models (third column) for 10\% of probability of exceedance in 50 (upper row) and 2634 (lower row) years (corresponding to return periods of 475 and 25000 years respectively). The map corresponding to the difference shows the variations of PGA when faults are introduced into the hazard computations as time dependent sources. Note the variations obtained when faults are used. Diamonds indicate the location of the highest PGA and the corresponding number indicates its value. The contour interval is indicated in each map. The dotted line bounds the study zone.

Fig. 10.- Mapa que muestra la distribución del PGA (aceleración pico del terreno) (modificado de Perea, 2006 y Perea y Atakan, 2007) correspondiente a un modelo que considera las fallas como fuentes dependientes del tiempo (columna del modelo de terremoto característico), a un modelo sin considerar las fallas (columna del modelo poisoniano) y a la diferencia entre ambos modelos (tercera columna), para un $10 \%$ de probabilidad de excedencia en 50 (fila superior) y en 2634 (columna inferior) años (correspondientes a periodos de retorno de 475 y 25000 años, respectivamente). El mapa correspondiente a la diferencia muestra la variación del PGA causadas por la introducción de las fallas como fuentes dependientes del tiempo en los cálculos de la peligrosidad. Nótese las variaciones que se obtienen cuando se utilizan las fallas. Los diamantes indican la localización de los mayores PGA y el número correspondiente indica su valor. El intervalo entre las isolíneas se indica en cada mapa. La línea de puntos limita la zona de estudio.

lumbrets basin is situated to the NE of the Cullera Cape. Towards the south of the basin, the seismic reflection profile SSP-7 (seismic survey SSP conducted by WESTERN in 1974; in Roca, 1992) shows some faults that displace the base of the Plio-Quaternary unit and one of them offsets reflectors close to the surface, suggesting that it is currently active. This fault trends NW-SE, dips to the NE and is $10 \mathrm{~km}$ long. It offsets the base of the Plio-Quaternary unit $0.07 \mathrm{~s} \mathrm{TWTT}$, which corresponds to $55 \mathrm{~m}$, assuming that $1500 \mathrm{~m} / \mathrm{s}$ is the propagation speed of the seismic waves. Thus, the slip rate of the fault varies be- tween 0.01 and $0.03 \mathrm{~mm} /$ year (Perea, 2006). In addition, this fault accounts for some of the instrumental seismicity in the vicinity.

\section{Final remarks}

Studies in active tectonics and paleoseismology have helped us to improve our understanding of the active faults in the northwestern margin of the València trough. This has resulted in the mapping of the active faults and has enabled us to calculate the parameters that describe 
their seismic cycle (Simón et al., 1983; Simón, 1984; Masana, 1995 and 1996; Masana et al., 2001a and 2001b; Santanach et al., 2001; Perea et al., 2003; Perea, 2006; Perea et al., 2006; Santanach et al., 2010). Finally, these faults have been included in a seismic hazard study in an effort to assess their contribution to the final results (Perea, 2006; Perea and Atakan, 2007).

The comparison of the location of the active faults ("faults with clear evidence of large paleo-, historic or instrumental seismicity"; "faults with evidence of accumulated activity during the Plio-Quaternary and with associated instrumental earthquakes"; "faults with evidence of accumulated activity during the Plio-Quaternary and without associated instrumental seismicity"; and "faults with associated instrumental seismicity and without evidence of accumulated activity during the PlioQuaternary") with the distribution of the historical and instrumental seismicity (Figs. 1 and 3), reveals a central zone, between Tarragona and València, with practically no instrumental seismicity. However, because this zone contains at least 16 active faults $\left(\mathrm{n}^{\circ} 6,7,8,9,10,11,12\right.$, 13, 14, 15, 16, 17, 18, 19, 20 and 21 in Fig. 8 and Table 1) it may have a high seismic potential. Since the València trough undergoes a low strain and experience very long average recurrent intervals, the seismic catalogs only cover a small part of the seismic cycle of the active faults. Therefore, given that one of these 16 faults, the southern El Camp fault, has been found to be seismogenic, it is reasonable to assume that these faults in this central zone can produce large earthquakes despite the absence of historical or instrumental seismic activity.

A seismic hazard study including the active faults was undertaken to evaluate the influence of their incorporation as time dependent seismogenic sources in a probabilistic assessment (Perea, 2006; Perea and Atakan, 2007). This showed that the inclusion of the faults increases the hazard values for different return periods between 475 and 25000 years around the zones where the faults are located when compared with calculations that did not consider faults (Fig. 10). Therefore, the integration of active faults to assess seismic hazard in zones of low seismic activity can produce significant changes in hazard values and hazard distribution.

Although the approaches proposed by Perea (2006) and Perea et al. (2006) enable us to evaluate the seismic parameters of a large number of the active faults in the northwestern margin of the València trough, numerous uncertainties remain. It is therefore essential to minimize these uncertainties in order to better understand the seismic behavior of the faults. To this end, paleoseismological studies are warranted especially on the faults that record significant accumulated activity although these do not show present seismicity.

\section{Acknowledgements}

The authors are indebted to Pilar Villamor and Daniela Pantosti for their helpful comments and suggestions which significantly improved the manuscript. The work of Hector Perea was undertaken at the IDL-UL Associated Laboratory under contract $n^{\circ} 3 / 2010 / L A B \_I D L$ and was co-funded by FCT and FEDER.

\section{References}

Agustí, J., Roca, E. (1987): Síntesis biostratigráfica de la fosa de la Cerdanya. Estudios Geológicos 43, 521-529.

Albini, P. (2000): Improving the knowledge of damaging earthquakes in south-eastern Spain (1500-1950).Technical report for the EC Project FAUST, Milano: $20 \mathrm{p}$.

Anadón, P., Cabrera, L., Calvet, F., Gallart, F., Lopez, C., Permanyer, A., Serra-Kiel, J. (1983): El Terciario. In: I.G.M.E. (ed.), Estudio geológico del Maestrazgo y de la mitad meridional de los Catalánides. Unpublished: 1-179.

Arasa, A. (1994): Estratigrafia i sedimentologia dels materials PlioQuaternaris del Baix Ebre i sectors adjacents. PhD Thesis. Universitat de Barcelona, Barcelona: 447 p.

Banda, E., Correig, A.M. (1984): The catalan earthquake of February 2, 1428. Engineering Geology 20, 89-97. doi:10.1016/00137952(84)90045-0.

Bisbal, L. (1984): Estudio de la distribución de intensidades sísmicas en el ámbito valenciano. Sus incidencias en las obras públicas. $\mathrm{PhD}$ Thesis, Universitat Politècnica de València, Valencia.

Briais, A., Armijo, R., Winter, T., Tapponnier, P., Herbecq, A. (1990): Morphological evidence for Quaternary normal faulting and seismic hazard in the Eastern Pyrenees. Annales Tectonicae 4, 19-42.

Bull, W.B., McFadden, L.D., 1977. Tectonic geomorphology north and south of the Garlock Fault, California. In: Doehring, D.O. (ed.), Geomorphology in arid regions. State Univ.of N.Y., New York: 115-138.

Burbank, D.W., Anderson, R.S. (2001): Tectonic geomorphology. Blackwell Science: 274 p.

Cabrera, L., Roca, E., Santanach, P. (1988): Basin formation at the end of a strike-slip fault: the Cerdanya Basin (eastern Pyrenees). J. Geol. Soc. London 145, 261-268. doi: 10.1144/gsjgs.145.2.0261.

Dewey, J.F., Helman, M.L., Turco, E., Hutton, D.H.W., Knots, S.D. (1989): Kinematics of the Western Mediterranean. In: Coward, M.P., Dietrich, D., Park, R.G. (ed.), Alpine Tectonics. Geol. Soc. London: 265-283.

Doglioni, C., Gueguen, E., Harabaglia, P., Mongelli, F., Durand, B., Jolivet, L., Horváth, F., Séranne, M. (1999): On the origin of the W-directed subduction zones and applications to the Western Mediterranean, The Mediterranean basins: Tertiary extension within the Alpine Orogene. Geological Society, London, Special Publications 156, 541-561. doi:10.1144/GSL.SP.1999.156.01.24.

Ferrer, P., Masana, E., Santanach, P. (1999): Expresión geomorfológica de la actividad reciente de la falla de Amer (NE de la Península Ibérica). Acta Geol. Hispánica 31, 17-24.

Fleta, J., Santanach, P., Goula, X., Martinez, P., Grellet, B., Masana, E. (2001): Preliminary geological, geomorphological and geophysical studies for the paleoseismological analysis of the Amer fault (NE Spain). Geologie en Mijnbouw-Netherlands Journal of Geosciences 80(3-4), 243-253. 
Font, E., Martínez-Solares, J.M., Masana, E., Santanach, P. (2010): La serie sísmica de Tivissa, 1845 (Cadenas Costeras Catalanas): Los deslizamientos del barranco de Manou. Rev. Soc. Geol. Esp. 23(1), 69-80.

Font, L., Baixeras, C., Moreno, V., Bach, J. (2008): Soil radon levels across the Amer fault. Radiation Measurements 43(Supplement 1), S319-S323.

Fontboté, J.M. (1954): Las relacciones tectónicas de la depresión del Vallès-Penedès con la Cordillera Prelitoral y con la depresión del Ebro. In: Tomo homenaje al profesor E. Hernández Pacheco. Rev. Soc. Esp. Hist. Nat., Spain: 281-310.

Fontserè, E. (1927): El temblor de tierra del 12 de Marzo del 1927. Revista Ibérica 23-IV-1327, p. 675.

Fontserè, E., Iglésies, J. (1971): Recopilació de dades sísmiques de les terres catalanes entre 1100 i 1906. Fundació Salvador Vives Casajuana, Barcelona: 548 p.

Gaspar-Escribano, J.M., García-Castellanos, D., Roca, E., Cloetingh, S. (2004): Cenozoic vertical motions of the Catalan Coastal Ranges (NE Spain): The role of the tectonics, isostacy, and surface transport. Tectonics 23, TC1004. doi:10.1029/2003TC001511.

Gasperini, P., Bernardini, F., Valensise, G., Boschi, E. (1999): Defining seismogenic sources from historical earthquake felt reports. Bulletin of the Seismological Society of America 89(1), 94-110.

Gelabert, B., Sabat, F., Rodriguez-Perea, A. (2002): A new proposal for the late Cenozoic geodynamic evolution of the western Mediterranean. Terra Nova 14(2), 93-100. doi:10.1046/j.13653121.2002.00392.x.

Goula, X., Olivera, C., Escuer, J., Fleta, J., Grellet, B., Bousquet, J.C. (1992): Neotectonics and seismicity of the area of the seismic crisis of 1427-28 in Catalonia. Proceedings of the 22nd General Assembly of the European Seismological Comission, Barcelona: 333-338.

Goula, X, Olivera, C., Fleta, J., Grellet, B., Lindo, R., Rivera, L., Cisternas, A., Carbon, D. (1999): Present and recent stress regime in the eastern part of the Pyrenees. Tectonophysics 308, 487-502. doi:10.1016/S0040-1951(99)00120-1.

Gueguen, E., Doglioni, C., Fernández, M. (1998): On the post-25 Ma geodynamic evolution of the western Mediterranean. Tectonophysics 298, 259-269. doi:10.1016/S0040-1951(98)00189-9.

Hamblin, W.K. (1976): Patterns of displacement along the Wasatch fault. Geology 4, 619-622. doi:10.1130/00917613(1976)4<619:PODATW >2.0.CO;2

Herraiz, M., de Vicente, G., Lindo-Ñaupari, R., Giner, J., Simón, J.L., González-Casado, J.M., Vadillo, O., Rodríguez-Pascua, M.A., Circuéndez, J.I., Casas, A., Cabañas, L., Rincón, P., Cortés, A.L., Ramírez, M., Lucini, M. (2000): The recent (upper Miocene to Quaternary) and present tectonic stress distributions in the Iberian Peninsula. Tectonics 19(4), 762-786. doi:10.1029/2000TC900006

IGME (1994): Mapa geológico de España. E. 1:1,000,000. I.G.M.E., Madrid.

Jolivet, L., Frizon de Lamotte, D., Mascle, A., Séranne, M., Durand, B., Jolivet, L., Horváth, F., Séranne, M. (1999): The Mediterranean basins: Tertiary extension within the Alpine Orogene, An introduction. In: Durand, B., Jolivet, L., Horváth, F., Séranne, M. (ed.), The Mediterranean basins: Tertiary extension within the Alpine Orogene. Spec. Publ. Geol. Soc., London, 156: 1-14. doi:10.1144/GSL. SP.1999.156.01.02.

Keller, E.A., Pinter, N. (1996): Active tectonics: earthquakes, uplift and landscape. Prentice Hall, New Jersey: 338 p.

Lewis, C.J., Vergés, J., Marzo, M. (2000): High mountains in a zone of extended crust: Insights into the Neogene-Quaternary topographic development of northeastern Iberia. Tectonics 19(1), 86-102. doi:10.1029/1999TC900056, 2000.

López Marinas, J.M. (1982): ¿Uno o dos terremotos catastróficos a fines del siglo XIV en el Reino de Valencia? Rev. Inst. Estudios Alicantinos 36, 59-72.

Malinverno, A., Ryan, W. (1986): Extension in the Tyrrhenian sea and shortening in the Appennines as result of the migration driven by sinking of the lithosphere. Tectonics 5, 227-245. doi:10.1029/ TC005i002p00227.

Masana, E. (1995): L'activitat neotectònica a les Cadenes Costaneres Catalanes. PhD Thesis. Universitat de Barcelona, Barcelona: 444 p.

Masana, E. (1996): Evidence for past earthquakes in an area of low historical seismicity: the Catalan coastal ranges, NE Spain. Annals of Geophysics 39, 689-704. doi:10.4401/ag-4000

Masana, E., Villamarín, J.A., Sánchez-Cabañero, J.G., Plaza, J., Santanach, P. (2001a): Seismogenic faulting in an area of low seismic activity: Paleoseismicity of the El Camp fault (Northeast Spain). Netherlands Journal of Geosciences / Geologie en Mijnbouw 80(34), 229-241.

Masana, E., Villamarín, J.A., Santanach, P. (2001b): Paleoseismic results from multiple trenching analysis along a silent fault: The El Camp fault (Tarragona, northeastern Iberian Peninsula). Acta Geológica Hispánica 36(3-4), 329-354.

McCalpin, J.P. (2009): Paleoseismology. International Geophysics series, Vol. 95. Elseiver, Academic Press: 647 p. doi:10.1016/S00746142(09)95001-X.

Medialdea, J., A. Maldonado, B. Alonso, J.L. Díaz, M. Farrán, S. Giró, A. Vázquez, E. Sainz-Amor, A. Martínez, T. Medialdea (1986): Mapa geológico de la plataforma continental española y zonas adyacentes, E. 1:200,000. Hoja 41-42 (Tortosa-Tarragona). I.G.M.E., Centro de Publicaciones Ministerio de Industria y Energia, Madrid.

Moissenet, E. (1989): Les fosses néogènes de la Chaîne ibérique: leur évolution dans le temps. Bull. Soc. Géol. France 8, 919-926.

Nuñez, A., I. Colodrón, V. Ruiz, I. Cabañas, A. Uralde, F. Abellán et al. (1980): Hoja Geológica num. 472 (Reus). Mapa geológico de España, E. 1:50,000. Primera edición. IGME, Madrid.

Ojeda, A., Atakan, K., Masana, E., Santanach, P., Jiménez, M.J., García-Fernández, M. (2002): Integration and influence of paleoseismic and geologic data fot the seismic hazard evaluation in the Catalan coastal ranges, Spain. Soil Dynamics and Earthquake Engineering 22, 911-916. doi:0.1016/S0267-7261(02)00114-8.

Olivera, C., Redondo, E., Lambert, J., Riera Melis, A., Roca, A. (2006): Els terratrèmols dels segles XIV i XV a Catalunya. Monografies n ${ }^{\circ} 30$. Institur Cartogràfic de Catalunya, Barcelona: 407 pp.

Olivera, C., Redondo, E., Riera, A., Lambert, J., Roca, A. (1999): Problems in assessing focal parameters to earthquake sequences from historical investigations: the 1427 earthquake in Catalonia. In: García García, J.M., Romacho Romero, M.D. (ed.), $1^{a}$ Asamblea Hispano-Portuguesa de Geodesia y Geofísica, Almería: Sim2-07.

Olivera, C., Susagna, T., Roca, A., Goula, X. (1992): Seismicity of the Valencia trough and surrounding areas. Tectonophysics 203, 99109. doi: 10.1016/0040-1951(92)90217-T.

Pantosti, D. (1997): Modern approaches in paleoseismology. In: Giardini, D., Balassanian, S. (ed.), Historical and prehistorical earthquakes in the Caucasus. Proceedings of the NATO Advanced Research Workshop, Armenia. Kluwer Academic Publishers, Dordrecht: 147-167.

Patriat, P., Segoufin, J., Schlich, R., Goslin, J., Auzende, J., Beuzart, P., Bonin, J., Olivet, J. (1982): Les mouvements relatifs de l'Inde, de l'Afrique et de l'Eurasie. Bull.Soc.Géol.France XXIV, 363-373.

Perea, H. (2006): Falles actives i perillositat sísmica al marge nordoccidental del solc de València. PhD Thesis. Universitat de Barcelona, Barcelona: 382 p. (http://hdl.handle.net/10803/1919)

Perea, H. (2009): The Catalan seismic crisis (1427 and 1428; NE Iberian Peninsula): Geological sources and earthquake triggering. Journal of Geodynamics 47(5), 259-270. doi:10.1016/j.jog.2009.01.002. 
Perea, H., Atakan, K. (2007): Influence of slow active faults in probabilistic seismic hazard assessment: the northwestern margin of the València trough. Natural Hazards 43(3), 379-396.

Perea, H., Figueiredo, P.M., Carner, J., Gambini, S., Boydell, K. and participants in the Europaleos (2003): Paleosismological data from a new trench across the El Camp Fault (Catalan Coastal Ranges, NE Iberian Peninsula). Annals of Geophysics 46(5), 763-774.

Perea, H., Masana, E., Santanach, P. (2006): A pragmatic approach to seismic parameters in a region with low seismicity: The case of eastern Iberia. Natural Hazards 39(3), 451-477. doi: 10.1007/ s11069-006-0013-y

Pitman, W.E., Talwani, M. (1972): Sea-floor sperading in the north Atlantic. Geol.Soc.Am.Bull. 83, 619-649. doi:10.1130/00167606(1972).

Reid, H. (1910): The mechanism of the earthquake, The California earthquake of April 18, 1906: Report of the State Eathquake Investigation Commission. Carnagie Institution, Washington D.C.: 192 p.

Ribera Faig, J.M. (1945): Observaciones sobre el Cuaternario de la comarca del Maresme. T. "Miscelánea Almera" 1" parte. Publ. Inst. Geol., Dip. Prov. Barcelona: 213-293.

Roca, E. (1992): L'estructura de la conca Catalano-Balear: paper de la compressió $i$ de la distensió en la seva gènesi. $\mathrm{PhD}$ Thesis. Universitat de Barcelona, Barcelona: $330 \mathrm{p}$.

Roca, E. (1996): La evolución geodinámica de la Cuenca CatalanoBalear y áreas adyacentes desde el Mesozoico hasta la actualidad. Acta Geol.Hispánica 29(1), 3-25.

Roca, E. (2001). The northwestern mediterranean basin (Valencia trough, Gulf of Lions and Liguro-Provençal basins): Structure and geodynamic evolution. In: Ziegler, P.A., Cavazza, W., Robertson, A.H.F., Crasquin-Soleau, S. (ed.), Peri-Tethys Memoir 6: Peri-Tethyan rift - Wrench basins and passive margins. Mem.Mus.National Hist.Nat. 186, Paris: 671-706.

Roca, E., Guimera, J. (1992): The neogene structure of the eastern Iberian margin: structural constraints on the crustal evolution of the Valencia trough (Western Mediterranean). Tectonophysics 203, 203-218.

Roca, E., Sans, M., Cabrera, L., Marzo, M. (1999a): Oligocene to middle miocene evolution of the central Catalan margin (northwestern Mediterranean). Tectonophysics 315(1-4), 209-233. doi: 10.1016/S0040-1951(99)00289-9

Roca, E., Sans, M., Cabrera, L., Marzo, M., Alvarez de Buergo, E., Marten, R., Villalobos, L., Varela, J. (1999b): Modelo tectonosedimentario del sector central y septentrional del margen catalán sumergido (cubetas de Barcelona, Sant Feliu, Begur y Riumors-Roses). In: Libro homenaje a José Ramírez del Pozo. A.G.G.E.P., Madrid: 199-217.

Royden, L.H. (1993): Evolution of the retreating subduction boundaries formed during continental collision. Tectonics 12, 629-638. doi:10.1029/92TC02641.

Sàbat, F., Roca, E., Muñoz, J.A., Vergés, J., Santanach, P., Sans, M., Masana, E., Estévez, A., Santisteban, C. (1997): Role of extension and compression in the evolution of the eastern margin of Iberia: the ESCI-Valencia Trough seismic profile. Rev. Soc. Geol. España 8, 431-448.

Santanach, P., Masana, E., Villamarín, J.A. (2001): Proyecto Datación. Consejo de Seguidad Nuclear, Barcelona: 159 p.

Santanach, P., Masana, E., Perea, H. (2010): The El Camp fault revisited: A $300 \mathrm{ka}$ long paleoseismic history of a low-slip normal fault in northeastern iberia. In: Insua-Arevalo, J.M., Martín-González, F. (ed.), Contribución de la geología al análisis de la peligrosidad sísmica. Primera reunión ibérica sobre fallas activas y paleosismología, Sigüenza, Guadalajara: 23-26.

Saula, E., Picart, J., Mató, E., Llenas, M., Losantos, M., Berasategui, X, Agustí, J. (1996): Evolución geodinámica de la fosa del Empordà ylas Sierras Transversales. Acta Geol. Hispànica 29, 55-75.

Savostin, L.A., Sibuet, J.C., Zonenshain, L.P., Le Pichon, X., Roulet, M.J. (1986): Kinematic evolution of the Tethis «calcalic» volcanism of Sardinia (Italy). Tectonophysics 123(1-4), 1-35. doi: 10.1016/0040-1951(86)90192-7.

Schindler, A., Jurado, M.J., Muller, B. (1998): Stress orientation and tectonic regime in the northwestern Valencia Trough from borehole data. Tectonophysics 300, 63-77. doi: 10.1016/S00401951(98)00234-0.

Schwartz, D.P. (1988): Geologic characterization of seismic sources: moving into the 1990's. Earthquake engineering and soil dynamics II proceedings. GT Division, ASCE, Park City, Utha, USA: 1-42.

Schwartz, D.P., Coppersmith, K.J. (1984): Fault behavior and characteristic earthquakes: examples from the Wasatch and San Andreas fault zones. Journ.of Geoph.Res. 89, 5681-5698. doi:10.1029/ JB089iB07p05681.

Serri, G., Innocenti, F., Manetti, P. (1993): Geochemical and petrological evidences of subduction of delaminated Adriatic continental lithosphere in the genesis of the Neogene-Quaternary magmatism of central Italy. Tectonophysics 223, 117-147. doi: 10.1016/00401951(93)90161-C.

Simón, J.L., Pérez, A., Calvo, A. (1983): Morfogénesis y geotectónica en el sistema de fosas del Maestrat (Provincia de Castellón). Estudios Geológicos 39, 167-177.

Simón, J.L. (1984): Compresión y distensión alpinas en la cadena ibérica oriental. PhD Thesis. Instituto de Estudios Turolenses, Teruel: 269 p.

Susagna, T., Goula, X. (1999): Catàleg de sismicitat. Atlas sísmic de Catalunya Vol. 1. Institut Cartogràfic de Catalunya, Barcelona: $436 \mathrm{p}$.

Vergés, J., Sàbat, F. (1999): Constraints on the Neogene Mediterranean kinematics evolution along a $1000 \mathrm{~km}$ transect from Iberia to Africa. In: Durand, B., Jolivet, L., Horváth, F., Séranne, M. (ed.), The Mediterranean basins: Tertiary extension within the Alpine Orogene. Special Publications, Geological Society, London 156: 63-80. doi:10.1144/GSL.SP.1999.156.01.05.

Vidal, N., Gallart, J., Dañobeitia, J.J. (1997): Contribution of the ESCI-València Trough wide-angle data to a crustal transect in the NE Iberian margin. Rev.Soc.Geol.España 8(4), 417-429.

Villamarín, J.A., Masana, E., Calderón, T, Julià R., and Santanach, P. (1999): Abanicos aluviales cuaternarios del Baix Camp (provincia de Tarragona): resultados de dataciones radiométricas. Geogaceta 25, 211-214.

Villamor, P., Berryman, K. R. (1999): La tasa de desplazamiento de una falla como aproximación de primer orden en las estimaciones de peligrosidad sísmica. Memorias $1^{\circ}$ Congreso Nacional de Ingenieria Sísmica, Murcia: 153-163.

Wallace, R.E. (1978): Geometry and rates of change of fault generated range fronts, North-Central Nevada. Journ.Res.U.S.Geol.Surv. 6(3), 637-650.

Wells, D.L., Coppersmith, K.J. (1994): New empirical relationships among magnitude, rupture length, rupture width, rupture area, and surface displacement. Bull.Seism.Soc.Am. 84(4), 974-1002.

Wesnousky, S.G. (1986): Earthquakes, quaternary faults and seismic hazard in California. Journal of Geophysical Research 91(B12), 12587-12631. doi:10.1029/JB091iB12p12587

Yeats, R.S., Sieh, K., Allen, C.R. (1997): Geology of earthquakes. Oxford University Press, New York-Oxford: 568 p.

Zarroca, M., Linares, R., Bach, J., Roqué, C., Moreno, V., Font, L., Baixeras, C. (2010): Integración de datos geofísicos y de medidas de gases en suelos como herramienta para la caracterización de una falla activa: El ejemplo de Amer (Pirineos, España). In: Insua-Arevalo, J.M., Martin-Gonzalez, F. (ed.), Contibución de la geología al análisis de la peligrosidad sísmica. Primera reunión ibérica sobre fallas activas y paleosismología. Sigüenza, Guadalajara: S4. 